\title{
Archaeological and Historical Investigations at Rancho de las Cabras, 41WN30, Wilson County, Texas: Fourth Season
}

Anne A. Fox

Brett A. Houk

Follow this and additional works at: https://scholarworks.sfasu.edu/ita

Part of the American Material Culture Commons, Archaeological Anthropology Commons, Environmental Studies Commons, Other American Studies Commons, Other Arts and Humanities Commons, Other History of Art, Architecture, and Archaeology Commons, and the United States History Commons

Tell us how this article helped you.

This Article is brought to you for free and open access by the Center for Regional Heritage Research at SFA ScholarWorks. It has been accepted for inclusion in Index of Texas Archaeology: Open Access Gray Literature from the Lone Star State by an authorized editor of SFA ScholarWorks. For more information, please contact cdsscholarworks@sfasu.edu. 
Archaeological and Historical Investigations at Rancho de las Cabras, 41WN30, Wilson County, Texas: Fourth Season

\section{Creative Commons License}

\section{(c) (i) (8)}

This work is licensed under a Creative Commons Attribution-NonCommercial 4.0 International License 


\section{Archaeological and Historical Investigations at Rancho de las Cabras, 41WN30, Wilson County, Texas: Fourth Season}

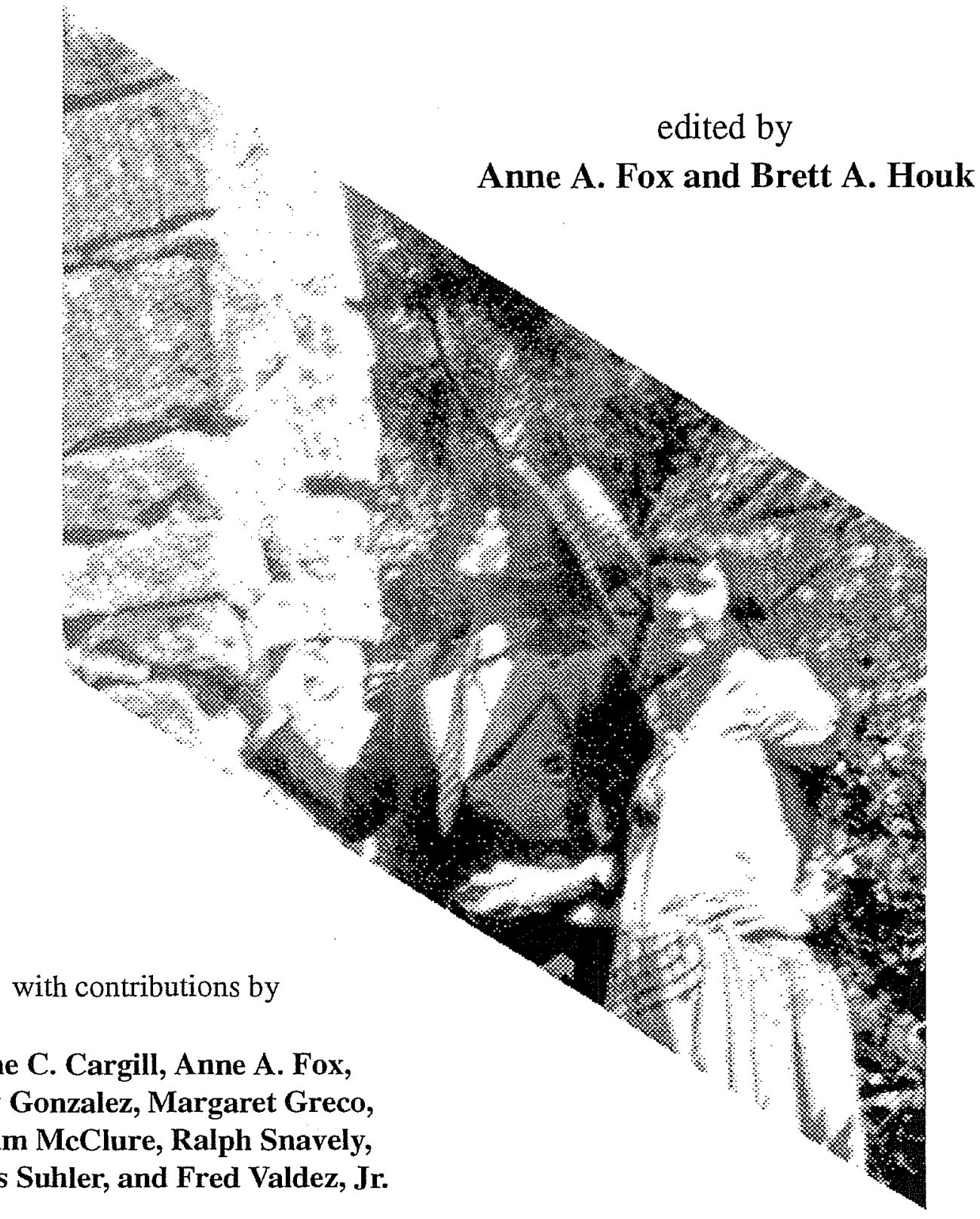

Diane C. Cargill, Anne A. Fox, Kathy Gonzalez, Margaret Greco, William McClure, Ralph Snavely, Charles Suhler, and Fred Valdez, Jr.

Center for Archaeological Research The University of Texas at San Antonio Archaeological Survey Report, No. 143 



\title{
Archaeological and Historical Investigations at Rancho de las Cabras, 41WN30, Wilson County, Texas: Fourth Season
}

\author{
edited by \\ Anne A. Fox and Brett A. Houk
}

with contributions by

Diane A. Cargill, Anne A. Fox, Kathy Gonzalez, Margaret Greco, William McClure, Ralph Snavely, Charles Suhler, and Fred Valdez, Jr.

\author{
Anne A. Fox \\ Principal Investigator
}

Texas Antiquities Permit No. 360

(C) copyright 1998

Center for Archaeological Research

The University of Texas at San Antonio

Archaeological Survey Report, No. 143 
The following information is provided in accordance with the General Rules of Practice and Procedure, Chapter 41.11 (Investigative Reports), Texas Antiquities Committee:

1. Type of investigation: Testing

2. Project name: Las Cabras IV

3. County: Wilson

4. Principal investigator: Anne A. Fox

5. Name and location of sponsoring agency: Texas Parks and Wildlife, Austin, Texas

6. Texas Antiquities Permit No.: 360

7. Published by the Center for Archaeological Research, The University of Texas at San Antonio, 6900 N. Loop 1604 W., San Antonio, Texas 78249-0658, 1998

A list of publications offered by the Center for Archaeological Research is available. Call (210) 458-4378; write to the Center for Archaeological Research, The University of Texas at San Antonio, 6900 N. Loop 1604 West, San Antonio, Texas 78249-0658; e-mail to car@lonestar.utsa.edu; or visit CAR's web site at http://www.csbs.utsa.edu/research/car. 


\begin{abstract}
During the month of July, 1983, the Center for Archaeological Research conducted a fourth season of excavations at Rancho de las Cabras (41WN30) near Floresville, Texas. Eleven excavation units were completed in the east part of the compound. Details of the construction of the south wall of Room 3 and the southeast portion of the compound wall were recorded. A trench for a palisade-type fence was located and followed out in the vicinity of the original northeast wall section. The fence was probably constructed for use in small livestock raising during the late eighteenth and early nineteenth centuries. Additionally, interviews with local informants were conducted to collect information about the history of the ranch.
\end{abstract}




\section{Acknowledgments}

Special thanks are due to Mr. and Mrs. Winston Southern, who kindly allowed the crew to cross their ranch in order to reach the site. Winston Davis, Secretary of the Wilson County Historical Commission and all around helper and good friend, eased our way through numerous organizational details. Sue Moss of the Texas Parks and Wildlife Department was instrumental in arranging for the oral history portion of the project. Local citizens were most helpful in arranging interviews and in searching back in their memories for information. We are grateful to Mr. and Mrs. Warren Zook, Mary Jane Moczygemba, Ignacio Flores, Andres Courvier, Mr. and Mrs. Ervin Albert, and Louis Ziegler.

The crew who worked on this season's project included Fred Valdez, Jr., Field Director, Anne Fox, Margaret Greco, Michaele Haynes, Kathy Gonzalez, Ralph Snavely, and Chuck Suhler. The crew members cooperated in writing the report, which was then edited by Fox and Brett A. Houk. 


\section{Contents}

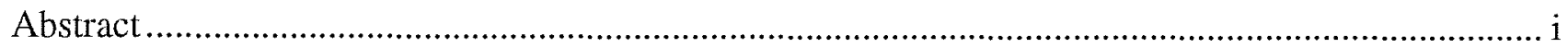

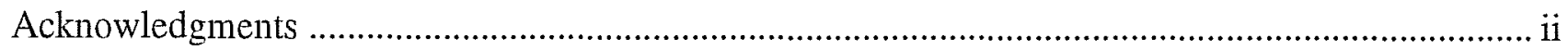

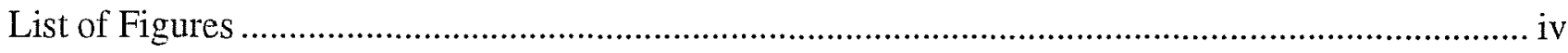

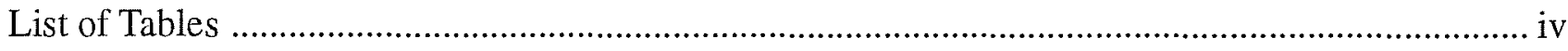



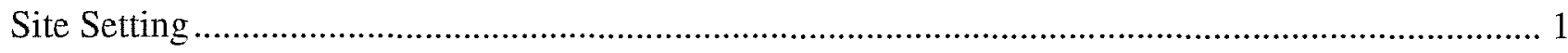

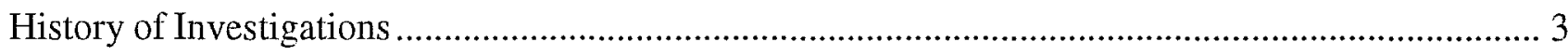

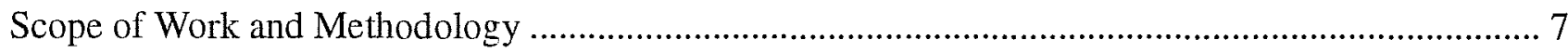

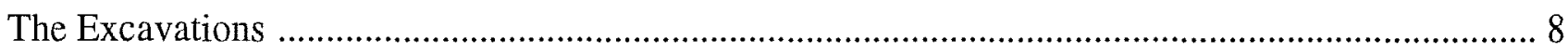

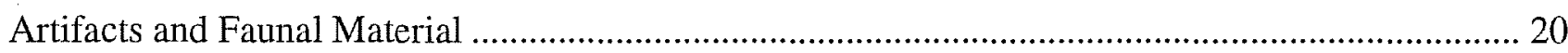

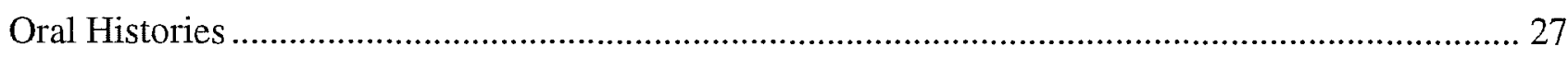

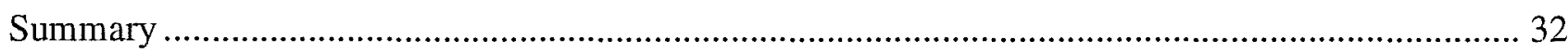

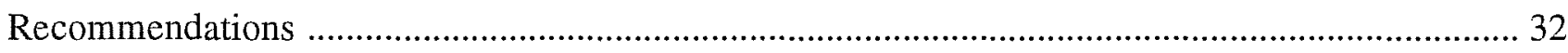

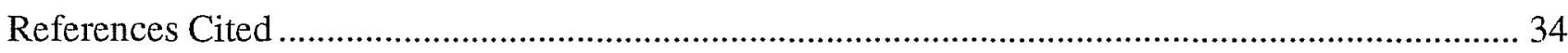




\section{Figures}

1. Location of las Cabras, Wilson County, Texas. ………….............................................................. 2

2. Map of ruins at las Cabras and 1980-1984 excavation units. ....................................................... 4

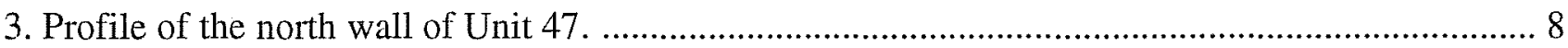

4. Plan of excavations in area of the original east wall of the compound. ......................................... 10

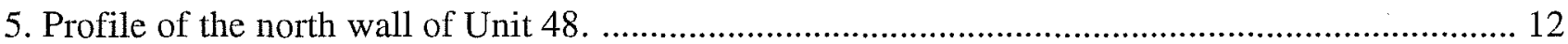

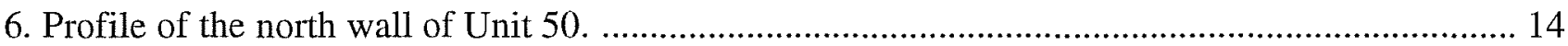

7. Plan of excavations in area of walls of Chapel and adjacent room. ............................................. 15

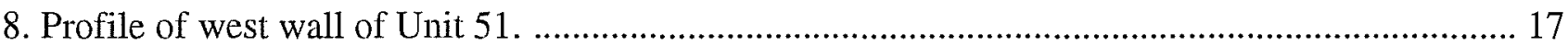

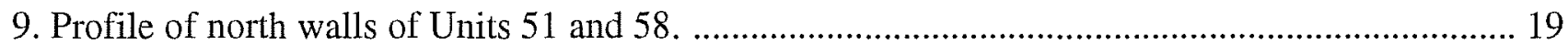

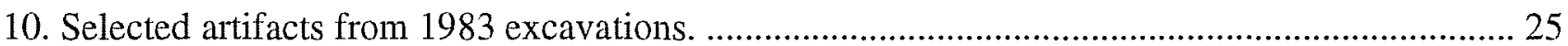

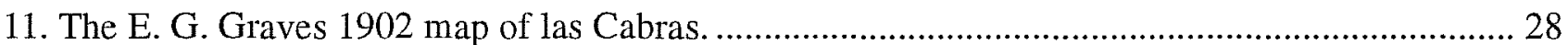

12. Photograph of Mr. and Mrs. Ervin Albert at las Cabras in 1927. ............................................... 31

\section{Tables}

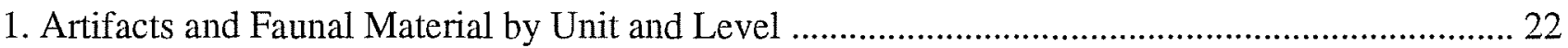

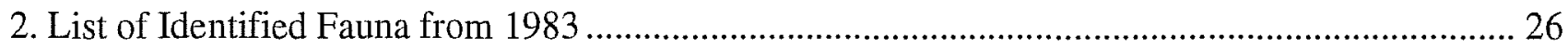




\section{Introduction}

Anne A. Fox

In July, 1983, the Center for Archaeological Research (CAR) at The University of Texas at San Antonio carried out the fourth season of investigations at Rancho de las Cabras, just south of Floresville, Texas (Figure 1). The excavations were sponsored by the Texas Parks and Wildlife Department (TPWD) in Austin, Texas, and were designed to provide both historical and structural information to be used in preserving the site as a historical park.

Rancho de las Cabras (41WN30) is listed on the National Register of Historic Places (NRHP) and is a State Archaeological Landmark (SAL). The construction of a visitor's center and the opening of the ranch site to the public were at that time included in the development plans of TPWD. Investigations were carried out under Texas Antiquities Committee Permit No. 360. Three previous seasons of excavations had been carried out at the site by CAR (Ivey and Fox 1981; Ivey 1983; Jones and Fox 1983). The 1983 season's field work was authorized by an interagency contract between the State of Texas and CAR. The principal investigator was Dr. Thomas R. Hester, thendirector of CAR. The co-principal investigators were Jack D. Eaton, then-associate director of CAR and Anne A. Fox, research associate. The permit was later transferred to Anne A. Fox. Field activities were directed by Fred Valdez, Jr.

The field crew consisted of the following CAR personnel: Kathy Gonzalez, Margaret Greco, Michaele Haynes, Ralph Snavely, and Chuck Suhler. Anne Fox also served as advisor for the excavations and conducted the oral history interviews. William McClure conducted the analysis of the animal bone materials recovered during this season's field work. The original illustrations were done by Margaret Greco and David Hafernik, several of which were redrafted by Chris Butler. The materials recovered and all maps, field notes, and records are curated at CAR.

Before the report on the 1983 excavations was completed, a fifth season of work at las Cabras took place in 1984 and was duly reported (Taylor and Fox 1985). Owing to various factors, completion of the fourth season's report has been delayed until this year, accounting for its appearance out of sequence. At the time this project was conducted, the site belonged to TPWD. In 1995, the ownership of the site was transferred to the National Park Service (NPS) to become a part of the San Antonio Missions National Historical Park.

\section{Site Setting}

\section{Diane A. Cargill}

Rancho de las Cabras is approximately four kilometers southwest of Floresville and two kilometers west of the confluence of the San Antonio River and Picosa Creek in Wilson County. Located on a high point of land, the site overlooks the confluence of the San Antonio River and Picosa Creek (Figure 1). The elevated location of the site also provides an eastern panoramic view of the river valley. The site is located in the Post Oak Belt subregion of the Central Gulf Coastal Plain physiographic region (Black 1989).

The climate of Wilson County is classified as subtropical with humid, hot summers and mild, dry winters (Taylor 1977:95). Annual rainfall is 28.96 inches with the months of late spring and early fall having the highest monthly rainfalls. Temperatures range on an annual basis from below freezing to over $100^{\circ} \mathrm{F}$ with an annual daily average of $81.9^{\circ} \mathrm{F}$ (Taylor 1977:94-95).

The most commonly mapped soil series in the project area are Colibro (Ustochrepts, fine), Saspamco (Ustochrepts, fine), Wilco (Paleustalfs, fine), Coy (Argiustolls, fine), Elmendorf (Argiustolls, fine), and Floresville (Paleustalfs, fine) (Taylor 1977). Most of these soils (Wilco, Coy, Elmendorf, and Floresville) are mapped on stable upland landscape positions and exhibit morphological characteristics indicative of at least a Pleistocene age (Nordt 1996, 1997). These four soils are classified as Alfisols or Mollisols with clayrich subsoils and common accumulations of secondary carbonate nodules. Two (Colibro and Saspamco) 


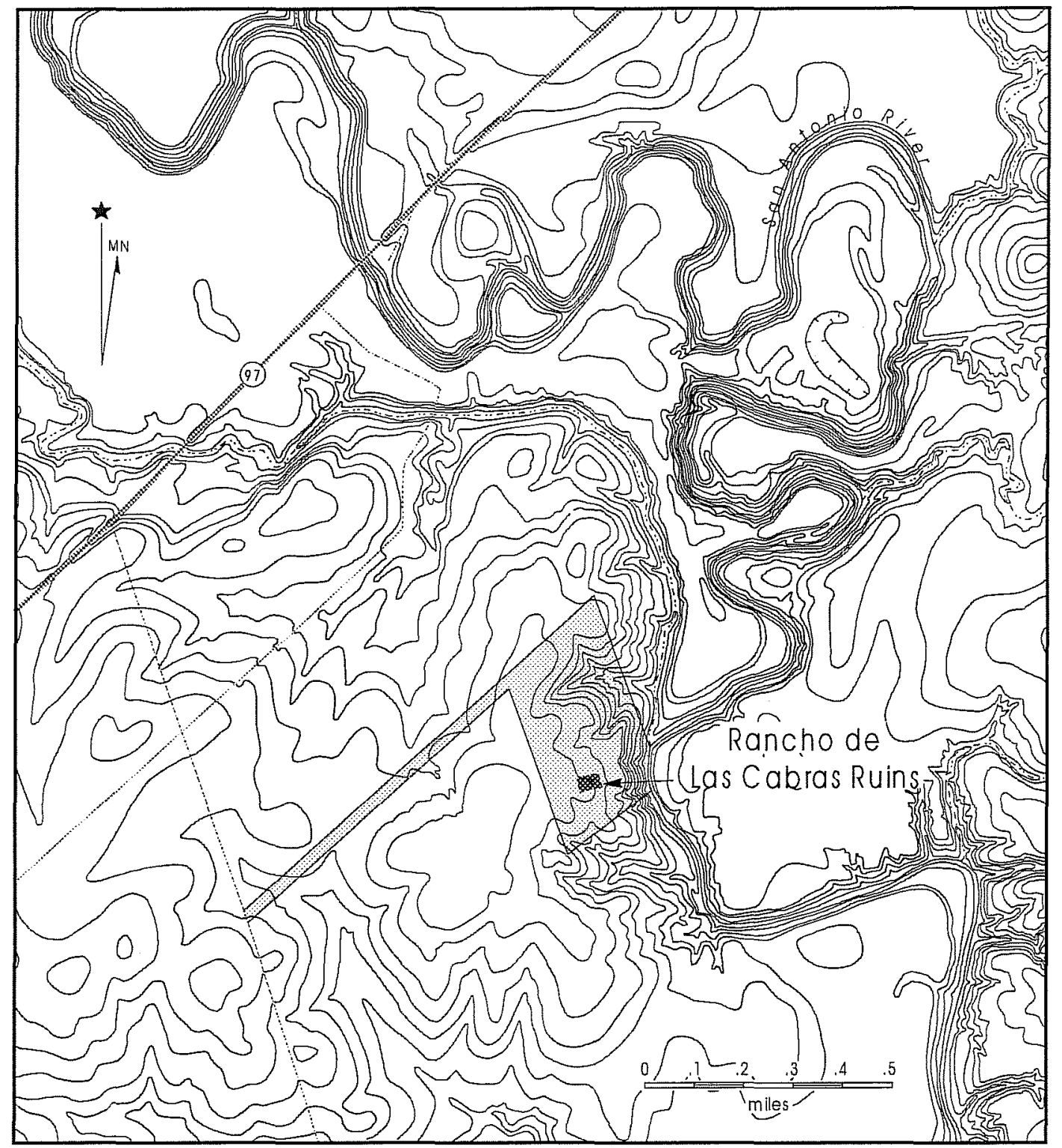

Figure 1. Location of las Cabras, Wilson County, Texas.

are Inceptisols, and these may represent soils that have formed on recently eroded surfaces.

The soils series within the broad alluvial valley of the San Antonio River are mapped primarily as Venus (Calciustoll, fine-loamy), Karnes (Ustochrept, coarseloamy), and Aransas (Haplaquoll, fine) (Taylor 1977). These soils usually exhibit considerably less pedogenic development than the upland soils. They are classified as Mollisols and Inceptisols with minor accumulations of secondary carbonate. These soils are indicative of Holocene ages (Nordt 1996, 1997).
Within the entrenched modern valley of the San Antonio River, the Loire-Frio, frequently flooded soils are mapped (Taylor 1977). These soils are classified as Ustifluvents (Loire) and Haplustolls (Frio). They are weakly developed Entisols and Mollisols typical of a late Holocene age (Nordt 1996, 1997).

The project area lies within the Tamaulipan Biotic Province region of south Texas (Blair 1950). Many of the modern-day floral communities prevalent in the area-including acacia, oak, ash, juniper, and spiny hackberry - appear to have been in the region for much of the Holocene (Labadie 1988:7). The mesquite chap- 
arral of modern south Texas is the product of the many environmental abuses that have occurred since the arrival of the first Europeans (Labadie 1988:7). Today in the project area, mesquite occurs along with thorny brush in the upland areas and the lands that have not been cleared for pasture (Ivey and Fox 1981:3). This type of secondary vegetation occurs in the immediate land around the Rancho de las Cabras ruins that in recent years was used for cattle grazing by the former owner (Winston Southern, personal communication 1997).

The modern fauna common to this region include 61 species of mammals, 36 species of snakes, 19 lizard species, and a variety of frogs and turtles (Blair 1950). Steele and Hunter (1986) suggest the fauna typical of the Tamaulipan biotic community has existed in the region for the last 2000 years and identify additional pre-European animals including, wild turkey, alligator, opossum, pronghorn, bison, white-tailed deer, peccary, bobcat, jackrabbit, and cottontail rabbit.

\section{History of Investigations}

\author{
Diane A. Cargill
}

The las Cabras structural site is an irregularly shaped compound with several rooms attached to the inside of the north wall (Figure 2). Grid north has been consistently set perpendicular to the longest face of the compound. The chapel is located in the eastern section of the compound. Traces of earlier walls show that the site has undergone major renovations including the addition of defensive bastions at the northwest and southeast corners of the compound. Details of construction and renovations of the ranch site have been reviewed by Ivey (1983) and Jones (Jones and Fox 1983). Three seasons of archaeological excavations were conducted at las Cabras by CAR for TPWD prior to 1983 (Ivey and Fox 1981; Ivey 1983; Jones and Fox 1983). A fifth season was conducted in 1984 (Taylor and Fox 1985). Each of these is summarized below. The various excavation units excavated during all five field seasons are included on Figure 2.

\section{First Field Season, 1980}

Field work was carried out from late June 1980 to the end of July 1980. The 1980 season was the first testing project at las Cabras, and little was known about the archaeology and the history of the site. The goals of this season were to determine the vertical and horizontal extent of the cultural deposits, identify architectural features and the type of materials used in the construction of those features, locate trash middens, and, lastly, identify (if such existed) non-cultural resource areas to be used in the future development of a visitor's center and access road to Rancho de las Cabras (Ivey and Fox 1981).

Three shovel tests (STs 1-3), and 14 test units (Units 2-15) were excavated. Note that Unit 1 was established but not dug. Excavation units ranged in size from $1 \times 1 \mathrm{~m}$ to $2 \times 3 \mathrm{~m}$. Units were excavated by natural strata and screened through $1 / 4$-inch hardware cloth. The entire project area was surveyed and surface collected (Ivey and Fox 1981).

The 1980 investigation identified the following: standing sandstone block walls up to 5 and 6 feet high along the compound's north wall, a room designated as the chapel, an apparent northwest gateway, three rooms of stonewall construction located south of the north compound wall, and a possible trash pit north of the north compound wall (Ivey and Fox 1981). Various other features uncovered included a possible well, a section of a plaster floor, occupation surfaces of hardpacked tan clay, hearth features, post holes, a jacal wall trench, manure layers, and disturbed areas presumably associated with pot hunters' backdirt (Ivey and Fox 1981).

CAR and TPWD produced a map of Rancho de las Cabras illustrating the compound walls, chapel, northern rooms and excavation units. During the survey part of the 1980 investigation, a limited number of prehistoric lithic artifacts were recovered. These artifacts were located mainly along the northern quarter of the northeastern fence line and are probably from an aboriginal site across the fence line to the northeast (Ivey and Fox 1981). Other chert fragments observed during the survey were determined to be a result of plow manufacture (Ivey and Fox 1981). 


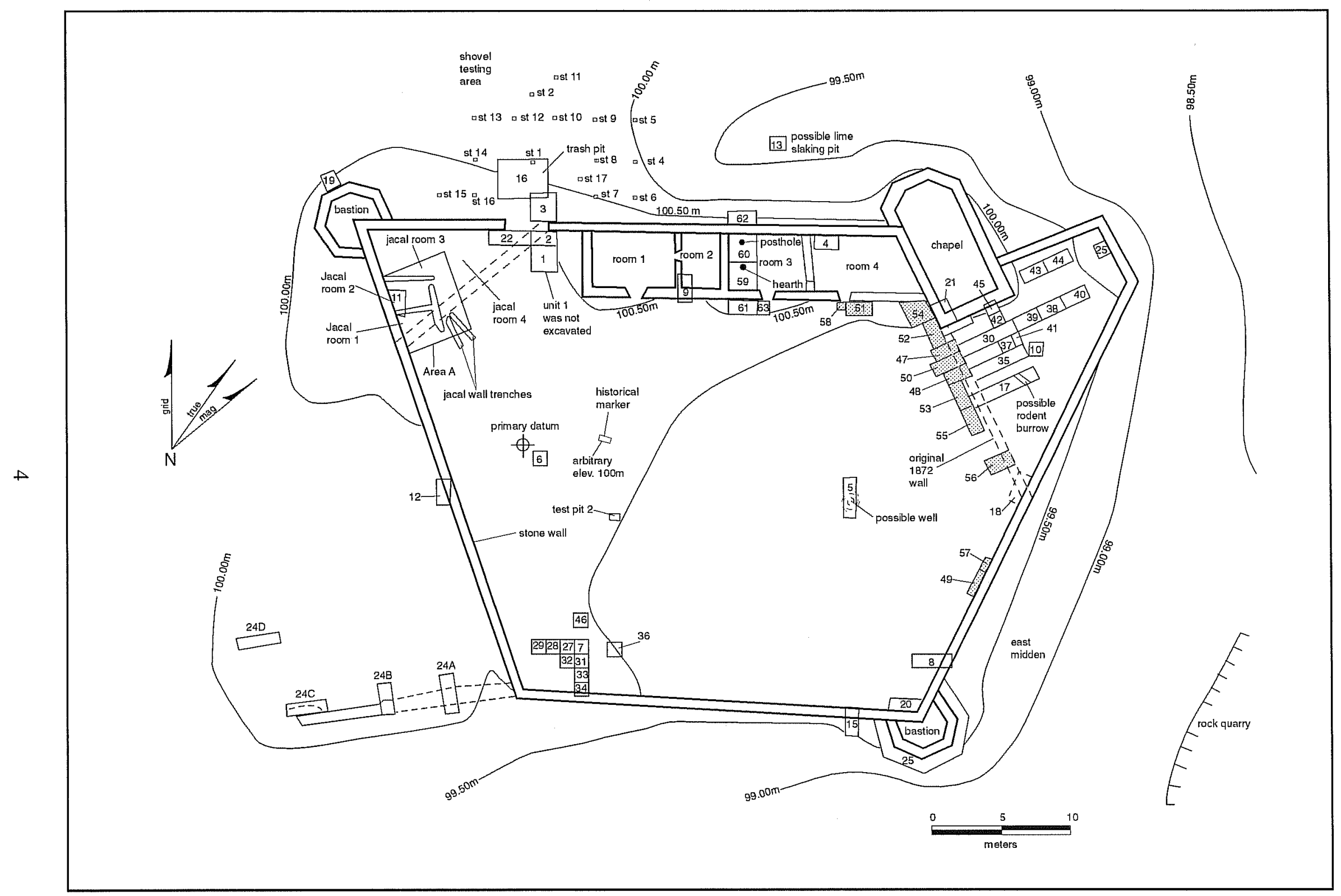

Figure 2. Map of ruins at las Cabras and 1980-1984 excavation units. 1980: Units 1-15, STs 1-3; 1981: Unit Area A, Units 16-25; 1982: Units 27-46; 1983: Units 47-58 (shaded) ; 1984: Units 59-63, STs 4-17. 
Cultural material in the form of ceramics, building materials, glass, metal, and stone objects recovered from the compound area point to a major occupation of the site from approximately 1760 to 1820 (Ivey and Fox 1981). Recovered faunal remains indicate that the occupants consumed both wild (e.g., squirrels, rabbits, turkey, javelina, fish, and turtles) and domesticated animals (e.g., cattle, goat/sheep, European pig, chicken). Cultural material representative of the nineteenth and twentieth centuries indicates that no significant occupation occurred after about 1810 (Ivey and Fox 1981).

\section{Second Field Season, 1981}

A second season of field investigations was conducted by CAR during July and August of 1981. Archival research was performed concurrently with the field work. The ranch compound had been defined by the end of the 1980 field season. The goal of the 1981 investigation was to explore further the compound area for evidence of cultural activity, architectural tracings. and stratigraphic sequences (Ivey 1983). Excavations were conducted throughout the compound in 1981 (Figure 2). The northwest area of the compound was investigated for activity areas and other cultural traces within and outside the jacal wall trenches identified in 1980. Additionally, the trash midden first encountered in 1980 was subjected to a more thorough investigation. Excavation units in the northeastern corner of the compound were dug to locate the front of the chapel, gather architectural and stratigraphic information, check for the presence of an earlier compound wall noted in 1980, and to locate the position of the northeastern end of the north wall. In the southwest area of the compound, traces of a wall extending west from the southwest corner of the compound were observed and investigated (Ivey 1983).

Thirteen excavation units (16-25, 24A-D, and Unit Area A) were excavated during the 1981 field season (Ivey 1983). These units ranged in size from $1 \times 1 \mathrm{~m}$ to $5 \times 6 \mathrm{~m}$ (Unit Area A). Units dug for stratigraphic information were excavated by natural stratigraphy and screened through $1 / 4$-inch hardware cloth. Units targeted at gaining architectural information were shoveled out and artifacts observed in the process were collected, but the soil was not screened (Ivey 1983).

The 1981 investigations documented the original east wall of the compound (Figure 2). Also observed was the intersection of the original east wall with the later addition of the new wall. A difference in the size and color of sandstone rock between the original and new walls was noted, however, time was limited to investigate this apparent difference (Ivey 1983). The front of the chapel was identified. Layers of manure believed to postdate the use of the chapel were observed. Large stones were found lying on the occupation surface, indicating the decay of the church prior to manure accumulation. Two bastions were identified, one located in the southeast and the other in the northwest sections of the compound. Rubble was cleared until the tops of the wall remains were clearly defined (Ivey 1983). Bastion walls and all perimeter compound walls were $66 \mathrm{~cm}$ thick. A wall-like structure was defined adjoining the southwest corner of the compound wall and extending to the west. Vertical and horizontal excavations were insufficient to determine the true nature of this feature. It appeared to have a very shallow foundation, if any, and no footing trench was observed (Ivey 1983).

The excavation of the trash pit identified in 1980 demonstrated that not one, but at least four overlapping trash pits were present. The volume of the faunal material was too great and the remains (articulated bone) too informative to be recovered during the 1981 season, so this important source of information was covered and left for future investigation. Area A contained trenches and post holes comprising four separate jacal rooms, three hearths, occupation floors, a stone wall footing for the original compound wall, and a lime kiln.

The artifacts recovered from the 1981 investigation continued to demonstrate that the main occupation of Rancho de las Cabras occurred between the years of 1760 and 1820 (Ivey 1983). Late nineteenth and twentieth century occupation of the site (as reflected in artifact type and density) was interpreted to be the result of intermittent visits by local hunters, picnickers, and treasure hunters (Ivey 1983). 


\section{Third Field Seasons, 1982}

CAR returned to Rancho de las Cabras for a third time in June of 1982. Both field work and archival research were undertaken as part of this investigation. Based upon the results of the 1980 and 1981 investigation, the goals in 1982 were to continue testing within the compound's stone wall enclosure for evidence of construction and occupation activity and to investigate the area adjacent to the chapel for the possible existence of burials (Jones and Fox 1983).

Twenty excavation units (27-46) were dug in 1982 (Figure 2). These units ranged in size from $1 \times 1 \mathrm{~m}$ to $1 \times 4.4 \mathrm{~m}$ (Jones and Fox 1983). In addition, two 50$\mathrm{x}-75-\mathrm{cm}$ test pits were excavated. All units were excavated by natural strata using a trowel or shovel. The soil removed during trowel excavation was screened through $1 /$-inch hardware mesh screens. Soil excavated by shovel was peeled off in thin layers and visually examined for cultural materials (Jones and Fox 1983). The northeast corner of the compound (south and east of the chapel) was selected for investigation to document the presence of burials. The southwest corner of the compound was chosen for further work because the 1980 and 1981 investigations demonstrated this area's potential for containing early construction information (Jones and Fox 1983).

Excavations in the southwest corner of the compound were not able to document early jacal structures in this area (Jones and Fox 1983). Two overlapping post holes were revealed in Unit 34 in line with the post hole documented in Unit 7 during the 1980 investigation, however, jacal wall trenches were not observed (Jones and Fox 1983). These post holes may represent the remains of a ramada or perhaps a livestock enclosure (Jones and Fox 1983). No burials were located in the northeast corner of the compound; however, structural and non-structural features which both predate and postdate the construction of the chapel were documented. These features include postholes, a jacal wall trench, areas of disturbance (assumed to be related to looting activities), and a shallow basin shaped pit (Jones and Fox 1983).

Artifacts recovered during the 1982 field season are similar to those recovered during the 1980 and 1981 investigations and reflect the same types and time period (Jones and Fox 1983). Faunal remains recovered during this project indicate that a wide variety of both wild and domesticated animals were consumed by the inhabitants of Rancho de las Cabras. By weight, however, cow bone provided the greatest representation of faunal material (McCLure 1983). McClure (1983) notes that many of the domestic species were killed as subadults.

\section{Fifth Field Season, 1984}

CAR conducted the last of five consecutive field seasons of excavations at las Cabras in late May and June of 1984. As part of this project, archival research was conducted by Dr. Thomas N. Campbell, professor emeritus of the Department of Anthropology. The University of Texas at Austin. The goals of the 1984 investigation included systematic shovel testing of the north midden to determine its vertical and horizontal extent, testing of the easternmost stone room located along the north compound wall, and excavation outside the south wall of stone rooms located along the north compound wall to determine the location of doors and windows (Taylor and Fox 1985).

Fourteen shovel tests (STs 4-17) were dug in the north midden area, several hand dug trenches were excavated along both faces of the east, south, and west walls of the four stone rooms, and five units were excavated inside and outside of Room 3 (Figure 2). The trenches were approximately $25 \mathrm{~cm}$ wide and $40 \mathrm{~cm}$ deep, and trench fill was not screened. Excavation units ranged in size from $1 \times 1 \mathrm{~m}$ to $2 \times 2 \mathrm{~m}$ and were excavated by natural strata. Wall fall rubble and backfill from looter's pits was not screened, however, all remaining matrix removed during the excavation of units was screened through $1 / 4$-inch hardware cloth (Taylor and Fox 1985).

The 1984 investigation provided additional data on the historic site of las Cabras. A selective surface collection of a midden east of the east compound wall indicates that this feature dates to the mid-1700s and is contemporaneous with the north midden (Taylor and Fox 1985). Shovel tests excavated in the north midden demonstrate that this feature may have a limited 
horizontal distribution. None of the shovel tests, with the exception of ST 7, encountered the north midden deposits observed in 1981 (Taylor and Fox 1985).

Excavation units placed outside the north compound wall of Room 3, inside Room 3, and adjacent to and south of Room 3 (in the plaza area) were excavated to provide a continuous profile of the deposits and additional information on the stratigraphic and construction sequence in the north compound area (Taylor and Fox 1985). What was once thought to be a single room (Room 3) was determined to actually be two rooms (Taylor and Fox 1985).

The majority of cultural material recovered during this investigation is indicative of the time period from ca. 1760 to 1820 (Taylor and Fox 1985). The majority of ceramic sherds are Goliad ware. Lithics and mussel shell, however, were recovered beneath the compound occupation surface and predate the site of Rancho de las Cabras. Due to a lack of diagnostic lithic material, this earliest occupation of the site cannot be dated (Taylor and Fox 1985). The majority of the faunal bone fragments are unidentifiable (Steele and DeMarcay 1985). However, several taxa are represented and Steele and DeMarcay (1985) provide an inventory of each by time period (i.e., pre-ranch, ranch, and postabandonment of the ranch). Dietary patterns observed include the presence of small fauna in the pre-ranch deposits, and large domestic species of cow, goat, and sheep in the deposits representative of the ranch and post use of the ranch. During the historic period, however, deer, turtles, alligators, fish, and birds are present (Steele and DeMarcay 1985:66). A large proportion of the cow, sheep, and goat apparently were killed as subadults. It is suggested that young and tender animals are selected when there are plenty of animals from which to choose (Steele and DeMarcay 1985). This is a pattern which was also observed by McClure (1983) in his analysis of the faunal material recovered during the 1982 investigation at Rancho de las Cabras.

\section{Scope of Work and Methodology}

\author{
Anne A. Fox
}

Goals for the 1983 season included: (1) the study of the construction history and sequential relationship between the chapel and adjacent walls and rooms; (2) a search for the location of the second gate/entrance or at least an attempt to narrow its probable location; and (3) the compilation of oral histories of area residents who remember visiting the site and know tales concerning the ranch.

The excavation units were established to determine architectural features and the relationship between features as dictated by the research goals. Twelve units were excavated in the 1983 field season in three areas (Figure 2). As in past seasons, unit numbers were assigned sequentially after those of previous years. A series of units $(47,48,50,52,53,55$, and 56) was placed along the location of the original east wall of the compound, first documented during the 1981 season (Ivey 1983). Three units (51, 54, and 58) were excavated along the southwest corner of the chapel and the south wall or Room 4. These ten units concentrated on establishing the construction history of the chapel, adjacent rooms, and remnant wall extending to the southeast. In a third area, two units (49 and 57) were excavated on the southeast wall. These were placed in hope of locating the second gate or entrance into the compound.

Excavation followed natural stratigraphy with assignment of successive numbers to the observed layers and soil deposits as they were encountered. Elevations were measured from a datum established at the base of the historical marker in the center of the compound. Some unit elevations were also measured from ground surface, with the unit datum elevation later measured in relation to the site datum.

All excavated material was screened through $1 / 4$-inch hardware cloth. Recovered artifacts were properly bagged with provenience and other appropriate data. Field records were made with the help of unit/level forms, which were then used for analysis of the results of the excavations. In addition, the crew drew plans and profiles of each unit as it was excavated, 
and at the end of the field work each crew member wrote a description of his or her unit and what had been found. These have formed the basis for all unit descriptions in this report.

\section{The Excavations}

compiled by Anne A. Fox

The 1983 excavations are described below. The individual unit discussions are organized by area, not sequentially, to facilitate comparisons between adjacent units with similar deposits.

\section{Investigations of the Original East Wall of the Compound}

\section{Unit 47}

Unit 47 was a 1-x-1-m excavation extending west from the original east wall of the compound (Figure 2). This unit was intended to locate the original east wall footing and to clarify the wall angle. It was also selected to locate any postholes which may be associated with those found in previous excavations on the east side of the original wall (Jones and Fox 1983). Layers 1 and 2 were not screened, but all artifacts observed were retained.

\section{Stratigraphy}

Layer 1, the surface layer, consisted of grass roots, small pebbles, and broken sandstone (Figure 3). The soil was red to tan and had a silty texture. An absence of topsoil was noted in a $50 \mathrm{~cm}$ linear area along the southeast corner of the unit, while a large root intrusion was observed in the northeast corner.

Layer 2 ranged from 6 to $24 \mathrm{~cm}$ in depth and receded from the east side of the unit to the west. The matrix within this layer was characterized by a fine red sandy loam, interspersed with patches of animal dung. A high concentration of large red sandstone fragments was found throughout the layer. A greater density, both in size and in number, was found in the northeast half of the unit as it approached the front of the chapel. Arti-
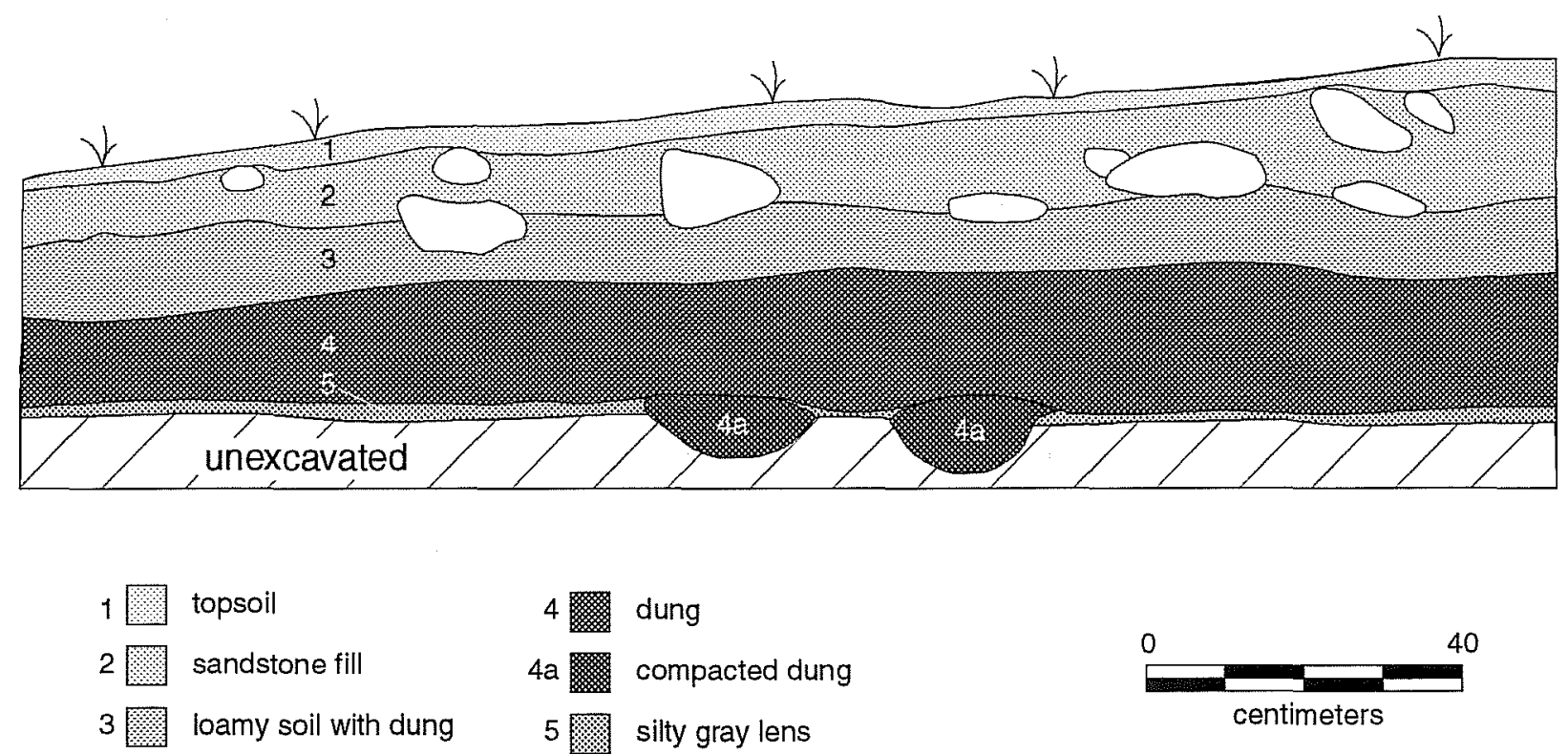

Figure 3. Profile of the north wall of Unit 47. 
facts retained included several small bits of unidentifiable metal.

Layer 3,8 to $14 \mathrm{~cm}$ in thickness, was composed primarily of a gray to brown sandy loam with soft, matted animal dung present throughout. This stratum overlies a much thicker and more compact layer of animal dung which forms the fourth layer.

Layer 4 was divided vertically into two components, each approximately $10 \mathrm{~cm}$ in thickness. The upper component was broken into small chunks of animal dung mixed with fine tan sand, while the lower component consisted of larger, more compact pieces of dung. Artifacts recovered through screening included an unglazed ceramic rimsherd and several metal scraps. A significant amount of animal bone was also present within this layer. Smaller pieces of bone were found to be associated with the upper component, while the larger fragments were associated with the lower component.

Layer 5 was 1 to $2 \mathrm{~cm}$ in thickness and consisted of a thin lens of gray to brown silty soil. This overlaid a compacted gray to brown occupation zone, embedded with small stones and animal bone which was not excavated. A subtle change in the hard-packed surface extended through the unit approximately $65 \mathrm{~cm}$ from the east wall. The consistency of this break is attributed to the footing trench of the original east wall of the compound. Two irregularly shaped, parallel trenches, each approximately $10 \mathrm{~cm}$ in width, were cut through the hard packed surface of the gray compacted soil, running north to south through the center of the unit. Hard-packed light tan dung was found within these trench intrusions. This dung differs from that above in its greater density and compactness. Several unglazed ceramic sherds were found within this layer as well as bits of charcoal and animal bone.

As this was cleared away, a series of postholes and shallow depressions was revealed within the trench. Loose soft gray silty soil was taken from around and in the postholes and shallow depressions within each trench. Postholes and depressions were numbered consecutively from north to south, and their contents were screened separately.

\section{Observations}

The oldest occupation surface found in this unit appears to be the unexcavated compacted soil at the bottom of the unit, the use of which was followed by a lengthy period of inactivity as indicated by the overlying lens of silt (Layer 5). At this point, an intense ranching operation seems to have concentrated in the east wall area, as suggested by the appearance of the trench line of postholes and shallow depressions originating from Layer 5 (Figure 4).

A period of inactivity followed as indicated by Layer 3, which was composed of a soft gray sandy loam with a small amount of animal dung. Layer 2, dominated by the appearance of sandstone debris, reflects a period of structural decay and/or abandonment, while the topsoil may show the effects of recent rodent activity.

The location of the east wall footing is observed in the bottom of Layer 5, making it possible to clarify the angle of the wall. The trench line of postholes and shallow depressions originated from roughly the same level as the posthole series found in the 1982 excavations (Jones and Fox 1983).

\section{Unit 52}

Unit 52 was a $1-\mathrm{x}-2-\mathrm{m}$ excavation located to the north of Unit 47 and overlapping the southwest corner of the chapel (see discussion of Unit 54 below). The intent of excavating this unit was to examine the relationship of the row of postholes encountered in Unit 47 to the chapel wall (Figures 2 and 4). Layers 1 and 2 were not screened, but observed artifacts were collected. 


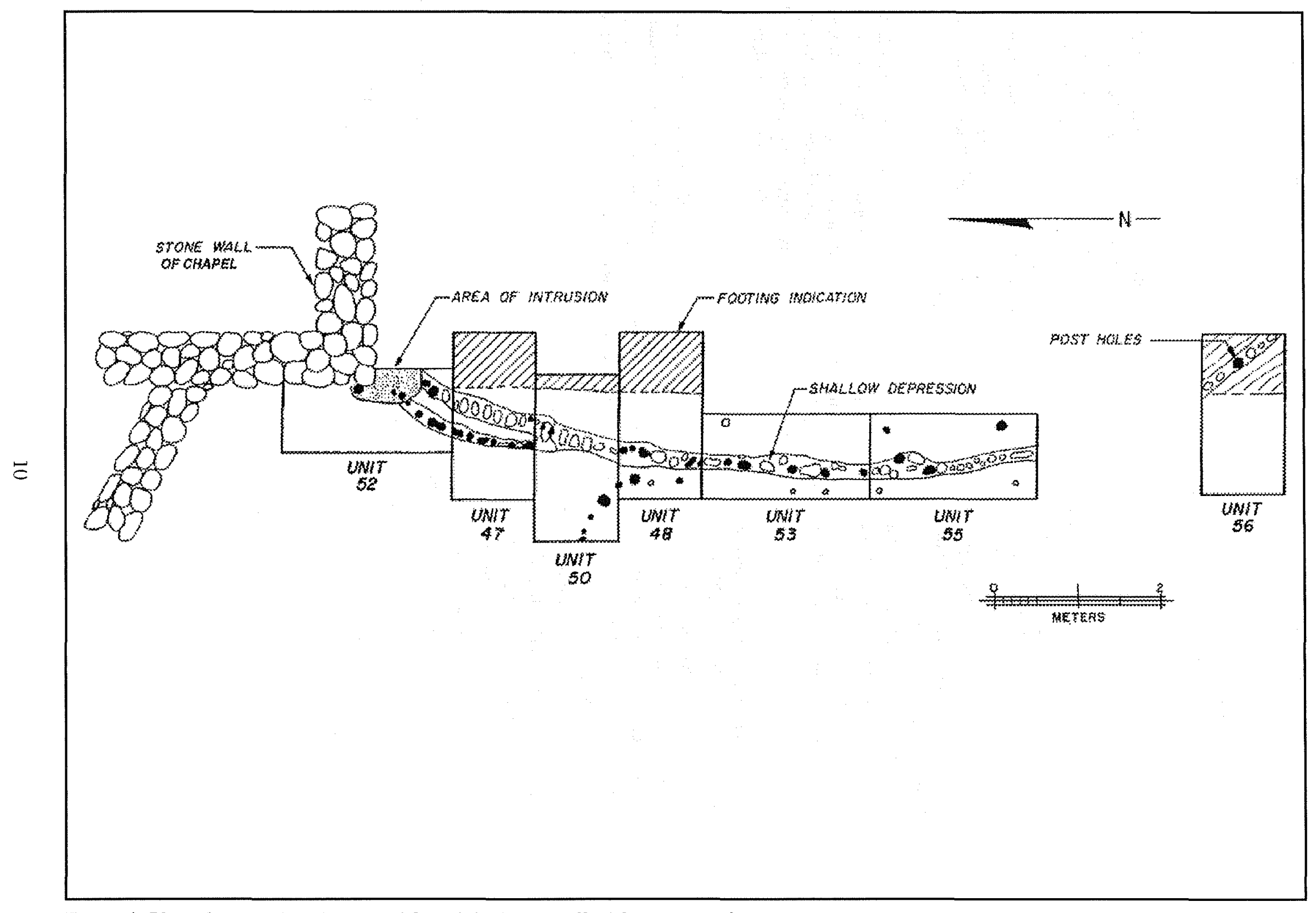

Figure 4. Plan of excavations in area of the original east wall of the compound. 


\section{Stratigraphy}

The surface layer of the unit consisted of a fine silty matter and was highly disturbed. Layer 2 contained two similar yet distinct areas within the unit. Layer $2 \mathrm{a}, 10 \mathrm{~cm}$ in depth and $40 \mathrm{~cm}$ in diameter, was located south of the south face of the wall of the chapel on the eastern edge of the unit. This layer contained red sandy loam mixed with a fine grayish silt and small sandstone pebbles. Layer $2 \mathrm{~b}$, also $10 \mathrm{~cm}$ deep, was present over the rest of the unit area as a fine red sandy loam interspersed with sandstone debris, the density of which receded from east to west within the unit.

Underlying Layer 2 a was a $30 \mathrm{~cm}$ thick light brown to gray sandy matrix mixed with small sandstone pebbles, which was designated Layer 3. This layer was found to overlay a $10 \mathrm{~cm}$ thick area of fine yellow sand which became Layer 4 .

Layer 5, which underlay Layer $2 b$, consisted of a mixture of silty gray brown soil interspersed with soft, matted animal dung. Bits of charcoal as well as isolated ashy lenses were also present.

Layer $6,20 \mathrm{~cm}$ wide and $10 \mathrm{~cm}$ deep, was located in the center of the western edge of the unit underlying Layer 5. This layer consisted of a dark, ashy and loamy soil with a thin layer of burned dirt extending into the profile. This was interpreted as the result of a burning tree root.

Layer 7 was present over the rest of the unit beneath Layer 5. This was a thick deposit of animal dung, 19 to $20 \mathrm{~cm}$ deep, and displayed two areas of differing qualities. The southern third of the unit was a very hard-packed light tan dung, similar to that in Unit 47. The rest of the layer was a softer and more loosely compacted dung within a red loamy matrix. In addition, several unglazed sherds and a significant amount of animal bone were recovered.

Layer 8 , a 1 to $3 \mathrm{~cm}$ deposit of gray brown silt, lay below the dung layer and was found throughout the remainder of the unit with the exception of the southeast corner where packed dung was found to continue, and formed the intrusive trenches extending from Unit 47.
Layer 8 overlay the surface of Layer 9, also found at this same level in Unit 47. The surface was found to be packed and embedded with stones, animal bone, and other debris. However, it was observed that in the northern half of the unit this surface was less packed and less embedded. A fine line of demarcation separating these two distinct areas was indicated by several aligned stones, running east to west across the unit.

An area approximately $30 \mathrm{~cm}$ in diameter was located just north of the intrusive Layers $2 \mathrm{a}, 3$, and 4 . This consisted of fine silty gray soil in a shallow depression originating from the surface of Layer 9.

Hard-packed dung was found within the two parallel trenches cutting into Layer 9 in the southwest corner of the unit. As this was cleared away, postholes and shallow depressions were revealed in the bottoms of both trenches.

Soft gray silty soil was found around and inside these postholes and depressions. The western trench contained four postholes. The eastern trench contained one shallow depression and two postholes. The relationship of these trenches to the chapel wall was obscured by the intrusion of Layers $2 \mathrm{a}, 3$ and 4 , which was identified in Unit 21, an excavation that took place during the second season at the site (Ivey 1983). A close examination of the bottom of that excavation revealed two postholes that lined up with the others in the western trench. Another possible posthole was found at the corner of the chapel wall.

\section{Unit 48}

Unit 48 was a $1-x-2-m$ unit placed with its northwest corner approximately $11 \mathrm{~m}$ from the outside edge of the juncture of the compound's original northeast and southwest walls (Figures 2 and 4). This area was chosen to provide information on the construction technique of this wall, a possible time frame of use, and explanation of its destruction. It was also hoped that more information would be garnered concerning the trenching and posthole episodes found in the nearby area during the previous season's testing (Jones and Fox 1983). 


\section{Stratigraphy}

Layers 1 and 2 combined ranged in depth from approximately $4 \mathrm{~cm}$ on the west wall of the unit to $32 \mathrm{~cm}$ on the east wall (Figure 5). They were composed of an orange tan loamy soil with a large accumulation of sandstone chunks covering the eastern third of the unit, thinning out both in concentration and in size toward the western edge. Artifacts in this layer included small fragments of animal bone (probably sheep/goat) and one small fragment of whiteware pottery all of which were found at the interface of Layers 2 and 3.

Layer 3 consisted of a grayish tan compact but powdery loamy soil with dung and charcoal flecks, ranging in depth from about $6 \mathrm{~cm}$ on the eastern edge of the unit to between 6 to $12 \mathrm{~cm}$ thick on the western wall, dipping slightly to the south. Two small animal bone fragments and a fragment of whiteware were found at the interface of Levels 3 and 4.
Layer 4 consisted of yellowish tan animal dung which was shoveled out as one layer, although at least five separate lenses could be observed. This layer was approximately $18 \mathrm{~cm}$ thick on the north wall of the unit and $24 \mathrm{~cm}$ thick to the south, dipping slightly toward the west. Artifacts in this layer consisted of animal bone fragments, probably sheep/goat, and also small fragments of charcoal, all of which appear to have been pressed into the top of each layer.

The dung deposit rested on a layer of fine, loose, yellowish-tan matrix (Layer 5) which covered the whole unit except for a trench line running $46 \mathrm{~cm}$ wide on the north wall of the unit and narrowing to approximately $20 \mathrm{~cm}$ wide at the southwest corner of the unit. Most of the accumulation of Layer 4 was removed along with Level 3; the rest was swept off the surface of Layer 5 to reveal two suggestive lines extending north-south across the surface of this stratum, as well as two postholes and a portion of a third on the western side of the unit. These postholes ranged from 10 to $15 \mathrm{~cm}$ depressions before they were cleaned out



Figure 5. Profile of the north wall of Unit 48. 
and their alignment strongly suggests a curving line of posts running from the northwest of the unit to the south unit wall.

The wide band of disturbance to the east of these postholes was filled with hard compacted dung which capped or spilled over onto the surface of the layer, giving the appearance that the trench was actually much wider. The trench for the postholes was dug from the surface of Layer 5. No post molds were observed.

On the eastern floor of the unit, beneath Layer 5, running from north to south and ca. $60 \mathrm{~cm}$ from the eastern unit wall, there was a band of fist-sized sandstone cobbles. This band follows the projected inner wall trench line for the original northeast compound wall.

Unit 48 was not excavated beyond Layer 5 . The posthole trench and the postholes were emptied out, and their positions, depths, and contents were recorded.

\section{Unit 50}

Unit 50 was a $1-\mathrm{x}-2-\mathrm{m}$ excavation placed between Units 47 and 48 in order to investigate further the trench sections found in those units (Figures 2 and 4). An additional purpose was to examine a larger sample of occupational floors on the west side of the original east wall.

\section{Stratigraphy}

Layers 1 to 5 of Unit 50 were cleared rapidly and not screened. They were found to be consistent with layers found above the old occupational surface of excavated units on either side (Figure 6). A thin layer of topsoil overlay a thick layer of fine reddish sandy loam mixed with sandstone debris forming Layer 2. The third layer consisted of a silty gray brown soil interspersed with animal dung. The thick deposit of animal dung, Layer 4, ended with a thin layer of silty gray soil recognized elsewhere as Layer 5.
Layer 6, a very hard packed gray silt mixed with stone, was approximately 6 to $10 \mathrm{~cm}$ thick. The surface of this layer was heavily packed and embedded with small unglazed sherds, stones, and animal bone. An intrusion, the extension of the trench found in Units 47 and 48 , was found to cut into Layer 6 and ran northsouth through the center of the unit.

Layer 7 was a light tan dung compacted within the trench. Like Units 47 and 48, this layer was more compact and contained a higher density of bone than that of the thick dung deposit of Layer 4 . Layer 7 was found to have postholes and shallow depressions in its bottom. Loose gray silt was found in the postholes and at the bases of the shallow depressions. The postholes were ca. 4 to $7 \mathrm{~cm}$ deep and contained small animal bone fragments.

Additionally, four postholes originating from within Layer 6 were found in the southwest corner of the unit. These ranged from 8 to $17 \mathrm{~cm}$ deep. Artifacts found included small bone fragments, a small unglazed sherd, and some bits of charcoal

\section{Unit 53}

Unit 53 was a $1-x-2-m$ unit laid out perpendicular to the west half of Unit 48 in order to follow out the line of the trench (Figures 2 and 4).

\section{Stratigraphy}

Layers 1 to 3 were shoveled out to the top of Layer 4, and were observed to be the same matrix that existed in Unit 48. The top of Layer 4 revealed a shallow depression in the dung which aligned in a rough arc from north to south with the trench of postholes in Unit 48 . Except in the area of arc-shaped disturbance, the dung popped off the surface below revealing the same light dusty blown-in deposit observed elsewhere as Layer 5. After removing this deposit, three postholes were seen, all ca. $10 \mathrm{~cm}$ in diameter and following the general line of the previously discovered trench. Artifacts recovered included animal bone, Goliad ware, and a chert projectile point. 


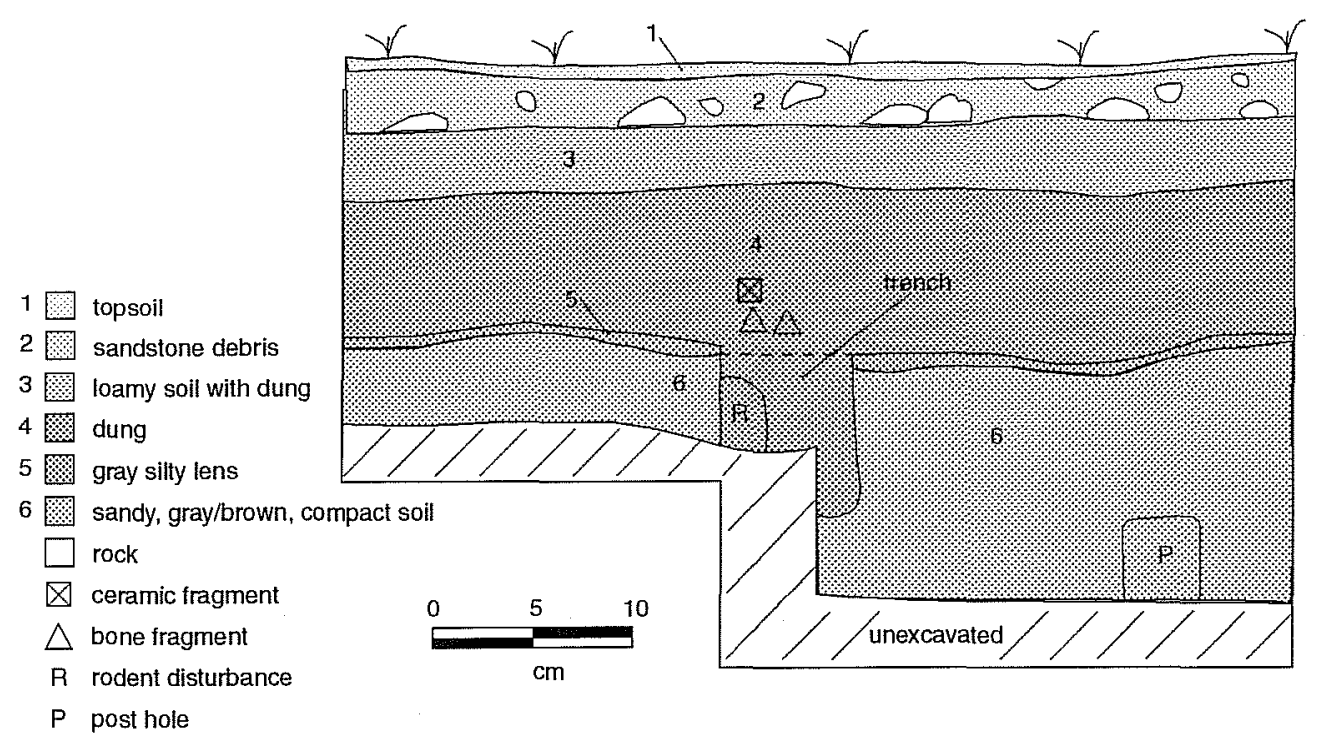

Figure 6. Profile of the north wall of Unit 50.

\section{Unit 55}

Unit 55 was a $1-x-2-m$ unit laid out as an extension of Unit 53 in order to follow out the trench across the area (Figures 2 and 4). The first three layers were shoveled off to the top of Layer 4 . The dung was then removed to reveal the line of the trench continuing. The postholes and shallow indentations continued in much the same fashion. Goliad sherds and several chert fragments were recovered.

\section{Unit 56}

Unit 56 was laid out two meters to the south of Unit 55 to follow out the line of the trench (Figures 2 and 4). An unexpected curve in the trench line put it in the eastern section of this unit, carrying it across the line of the buried footing of the original east wall of the compound. A posthole and a number of shallow depressions were found in this section of the trench. Artifacts recovered included fragments of bone and two lead glazed sherds, one sherd of majolica, and six sherds of Goliad ware.

\section{Investigations of the Walls of Chapel and Adjacent Room}

\section{Unit 54}

Unit 54 was established in the corner formed by the south wall of Room 3 and the west wall of the chapel (Figures 2 and 7). The purpose of the unit was to investigate the structural footings and their depth and to determine which structure was built first or if they were built at the same time.

\section{Stratigraphy}

Layer 1 was a very disturbed mix of rubble, soil, sand, and dung. The rubble was a mix of both red and yellow sandstone. The dung, when it appeared at the bottom of the layer, was sloping west to east, rather than building up against the wall as might be expected. In addition, there was a total absence of dung in a halfmeter diameter area in the northeast corner of the unit.

Layer 2 was the dung layer proper that terminated on a hard packed surface. Layer 3 was an area of ash and 


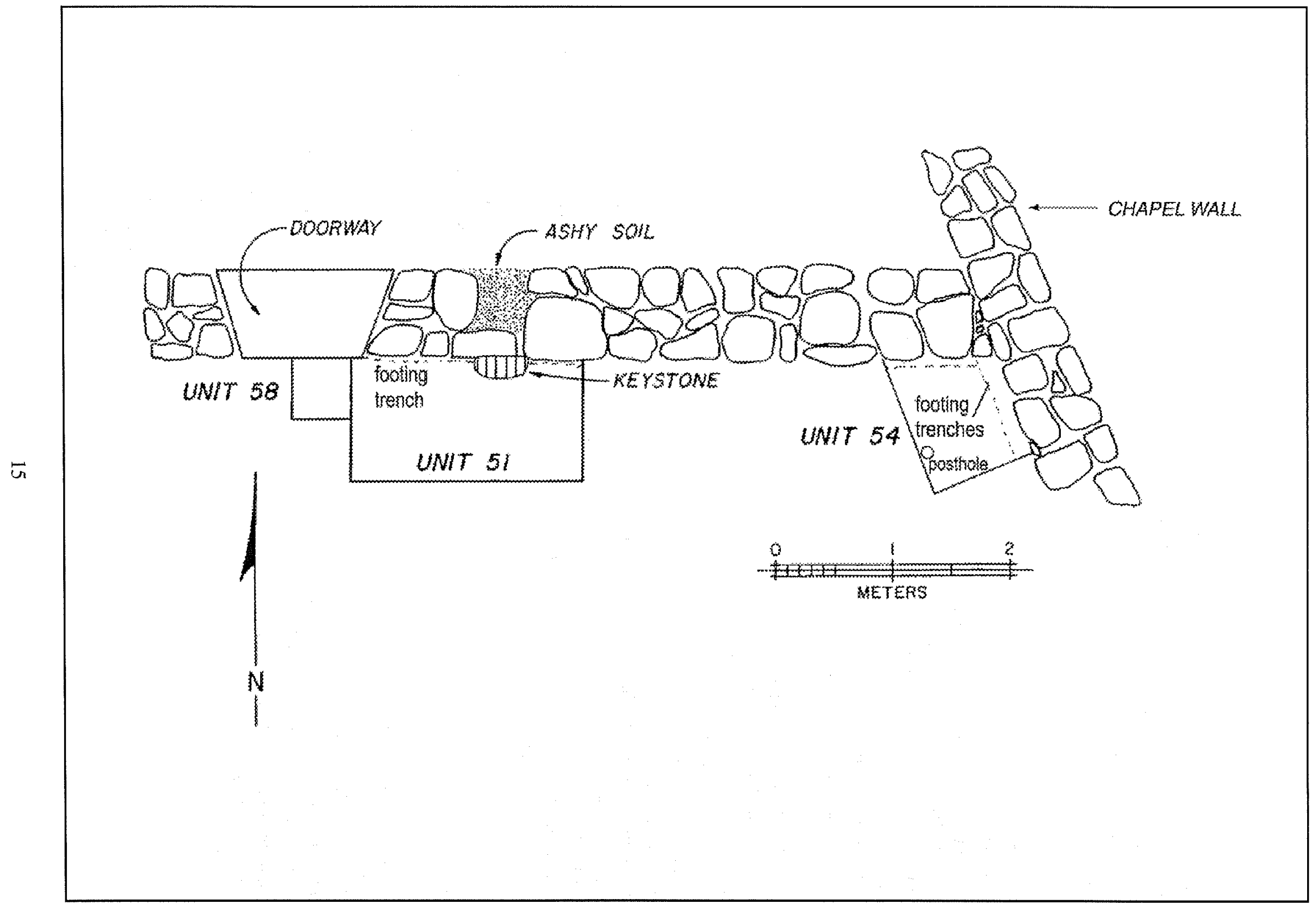

Figure 7. Plan of excavations in area of walls of Chapel and adjacent room. 
charcoal irregularly distributed on this surface. The beginning of the footing trench for the west wall of the chapel was visible at the bottom of Layer 3. The northern end of the footing trench was disturbed by a large rodent burrow in which the soil was dark and loose. A rodent skull was found in the burrow. The rest of the footing trench was filled with a loosely packed soil with some decayed red sandstone inclusions.

Layer 4 was a hard packed tan layer with charcoal and ash pockets, much of the contents coming out in large chunks. There was evidence of rodent and root activity throughout. In the west center of the unit was a posthole $20 \mathrm{~cm}$ in diameter, which probably originated in the overlying stratum. The depth of the posthole at this point was $25 \mathrm{~cm}$, with charcoal and ash present in the upper $10 \mathrm{~cm}$. Majolica, lead glazed, and Goliad sherds were recovered from this layer.

Layer 5 was a dense, hard packed gray silty soil with some charcoal and ash. It appeared to be at the bottom of the occupation layer, since the only artifact found was in the first few centimeters. The footing trench for the chapel wall showed up vividly as light gray in contrast to the rest of the unit. A $50 \mathrm{~cm}$ square excavation was made in the northeast corner of the unit to examine the footings for both walls. The bottom of the south wall of Room 3 was $117 \mathrm{~cm}$ below datum, while the bottom of the west wall of the chapel was $163 \mathrm{~cm}$ below datum.

\section{Observations}

Layer 1 was badly disturbed and yielded few artifacts. Layer 2 was essentially sterile. Layers 3 and 4 along with the very top of Layer 5 appear to be the main level of occupation. The evidence suggests that the chapel wall was built before that of Room 3. The Room 3 south wall butts against the chapel with no interdigitation of stone. Also, the footings are quite different in depth and construction.

\section{Units 51 and 58}

Unit 51 was a $1-x-2-m$ excavation located along the outside of the south wall of Room 3 (Figures 2 and 7). The excavation's eastern limit was 6.4 meters west of the west wall of the chapel and it extended two meters to the west. The northern limit of the unit was the outside face of the south wall of Room 3. The unit location was selected in order to investigate a stone which protruded from the wall, to record a possible doorway, and to document the type of footing used in the construction of the wall.

Unit 58 was a small, $50-\mathrm{cm}$-square unit connected to the west end of Unit 51 outside the south wall of Room 3 (Figures 2 and 7). The primary purpose of this unit was to expose a larger section of the doorway located in Unit 51. The stratigraphy of the two units is comparable.

\section{Stratigraphy}

Layer 1 was the ground surface removed during the initial wall clearing and cleanup (Figure 8). The original ground surface was uneven, with two large roots on the east side of the unit. The soil on the surface was a brown sandy loam mixed with wall rubble. One sherd of Goliad ware was recovered within this layer.

Layer 2 was a loosely packed tan to brown sandy loam containing many small rocks. These rocks were found to be approximately the same size, and small enough to be used as chinking in the wall. A small bone fragment, a piece of brown glass, and a rusty sardine can were recovered from this layer. Recorded ceramics include one Goliad and one lead glazed sherd.

Layer 3 began at ca. $26 \mathrm{~cm}$ below the surface where the soil became darker. The loosely packed brown sandy loam had small rocks occurring through the layer. Before the termination of this layer, a fine layer of loose fine brown sand with an almost dust-like quality was found. The depth of this material ranged from 1 to $8 \mathrm{~cm}$, with the deeper deposits occurring in small pockets created by an uneven surface. The fine brown sand may have represented windblown deposits. No artifacts were found in this sand. Artifacts recovered 


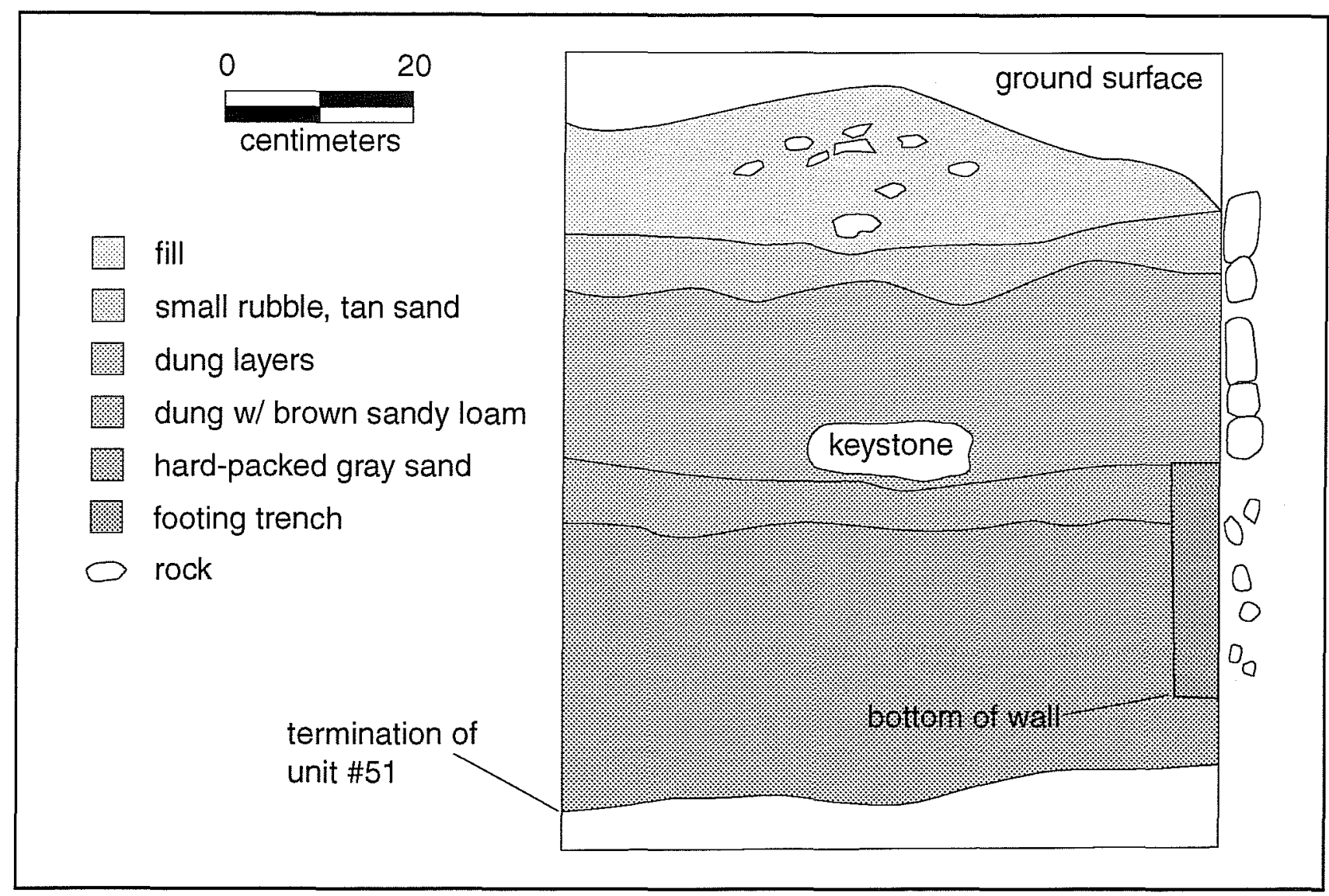

Figure 8. Profile of west wall of Unit 51.

from the darker brown layer included bone fragments, brown glass, a .22 caliber shell, sponge-printed whiteware, and Goliad ware. The layer terminated at $35 \mathrm{~cm}$ below the surface. A keystone-shaped stone was found resting on the interface between Layers 3 and 4 .

Layer 4 was loosely packed dung mixed with a brown sandy loam. Large stones were evident in the southeast corner of the excavation, and large bone fragments were recorded in the upper part of the layer. At approximately $41 \mathrm{~cm}$ depth the animal dung became lumpy and crumbly, with little or no sand and a white mold seemed to be present on the dung surface. At this depth the dung was tightly compacted. Bone was the most common artifact, type with one piece of chert and three pieces of rusted metal also present. In an area $5 \mathrm{~cm}$ wide along the wall was a friable dung and sand mix. This layer terminated at $57 \mathrm{~cm}$ below the surface.
Layer 5 was a hard packed gray surface, with charcoal flakes and ceramic fragments pressed into it. The large stones in the eastern half of the unit originated at this level. At $65 \mathrm{~cm}$ below the surface, the soil was still a hard packed sandy loam with charcoal flakes. The soil in the $5 \mathrm{~cm}$ strip along the wall was also hard packed, but of slightly different texture. Artifacts recovered from this level included a small piece of metal, five Goliad sherds, three lead glazed sherds, and fragments of bone and brown glass. Fragments of sandy brown lime mortar were also present. At $73 \mathrm{~cm}$ below the surface, a brown sandy loam occurred with no cultural materials. This marked the end of cultural indications except for the $5 \mathrm{~cm}$ band along the wall, which appeared to be a setting trench. This trench started at $57 \mathrm{~cm}$ below the surface and extended 40 $\mathrm{cm}$ to the termination of the footing. The footing trench stopped at a depth of $97 \mathrm{~cm}$. 


\section{Observations}

The stratigraphic sequence illustrates a number of events which took place. Each of the five layers represents a different situation. The hard packed gray surface represents the major occupation level. The fine dusty sand accumulated on top of this may have been a windblown deposit, perhaps indicating abandonment of the structure. Layers of dung accumulated on top of the sand suggest that the area was then used for holding livestock. Above the dung is a sand deposit with bits of wall rubble, probably representing abandonment and the start of wall disintegration. From this layer to the ground surface, tan soil fill and wall rubble occur, including a large amount of chinking stones.

These excavation units reveal the construction techniques used by the builders. A footing $35 \mathrm{~cm}$ deep and a bit wider than the wall was first dug into the gray hard packed occupation surface. This indicates that the wall construction came sometime after the origin of this surface. Into the footing trench, layers of mud were poured with small rocks added between each layer of mud, with the rocks gradually becoming larger in size with each layer of mud. The first row of rocks above the occupation surface was laid in mud and often pushed down at a slant into the footing trench. It was on top of this foundation that the cutstone wall was built (Figure 9).

The builders may have been planning another wall that would tie into the outside of the south wall of Room 3. A flat stone protruded from the wall into the unit one course above the top of the footing. This stone could be used to tie in another wall perpendicular to the existing wall. No evidence in the form of wall or footing remnants was found to indicate that the keystone had ever been utilized. If other similar stones were set higher up in the wall, they were destroyed in the destruction of the wall.

The doorway located in the northwest corner of Unit 51 and in Unit 58 did not have a cut threshold stone. Only footing stones were found at the base of the doorway.

\section{Architectural Investigations of the Southeast Wall}

\section{Unit 49}

Unit 49 was a $0.5-x-2-m$ excavation located inside the compound along the east wall, with the east edge of the wall being the east edge of the unit. The excavation's southern limit was $10 \mathrm{~m}$ south of the intersection of the east and south walls. Measurements were taken from the inside corner of that intersection. The unit location was selected for the purpose of recording the footing and other techniques used in the wall construction. It was placed in this location in an attempt to uncover a gate through the wall. In earlier seasons a concentration of discarded artifacts had been observed along the outside of the wall in this area, indicating the possible existence of a passageway in this section of the wall.

\section{Stratigraphy}

Layer 1 consisted of a brown sandy loam mixed with rubble that was removed during the initial wall cleaning. This layer, removed without screening, terminated at the top of the first dung layer at a depth of $14 \mathrm{~cm}$ below datum.

Layer 2 consisted of animal dung ranging from loosely packed to tightly packed clumps. In this unit the deposit was considered as one layer although it could have been split into several thinner layers. It contained large amounts of bone and charcoal. Also, a piece of red painted ceramic ware was recovered. This layer was ca. $13 \mathrm{~cm}$ thick throughout the unit.

On the surface of Layer 3, a sherd of Goliad ware was found. A burned area roughly rectangular in shape extended from the middle to the south end of the unit. An isolated piece of sandstone was observed sitting on this surface. There was a thin $1 \mathrm{~cm}$ layer of loosely packed gray soil on top of a tightly packed light gray ashy and sandy soil that contained flecks of charcoal. This layer was a total of $3 \mathrm{~cm}$ in thickness. Six sherds of Goliad ware and a large amount of bone were recovered. 


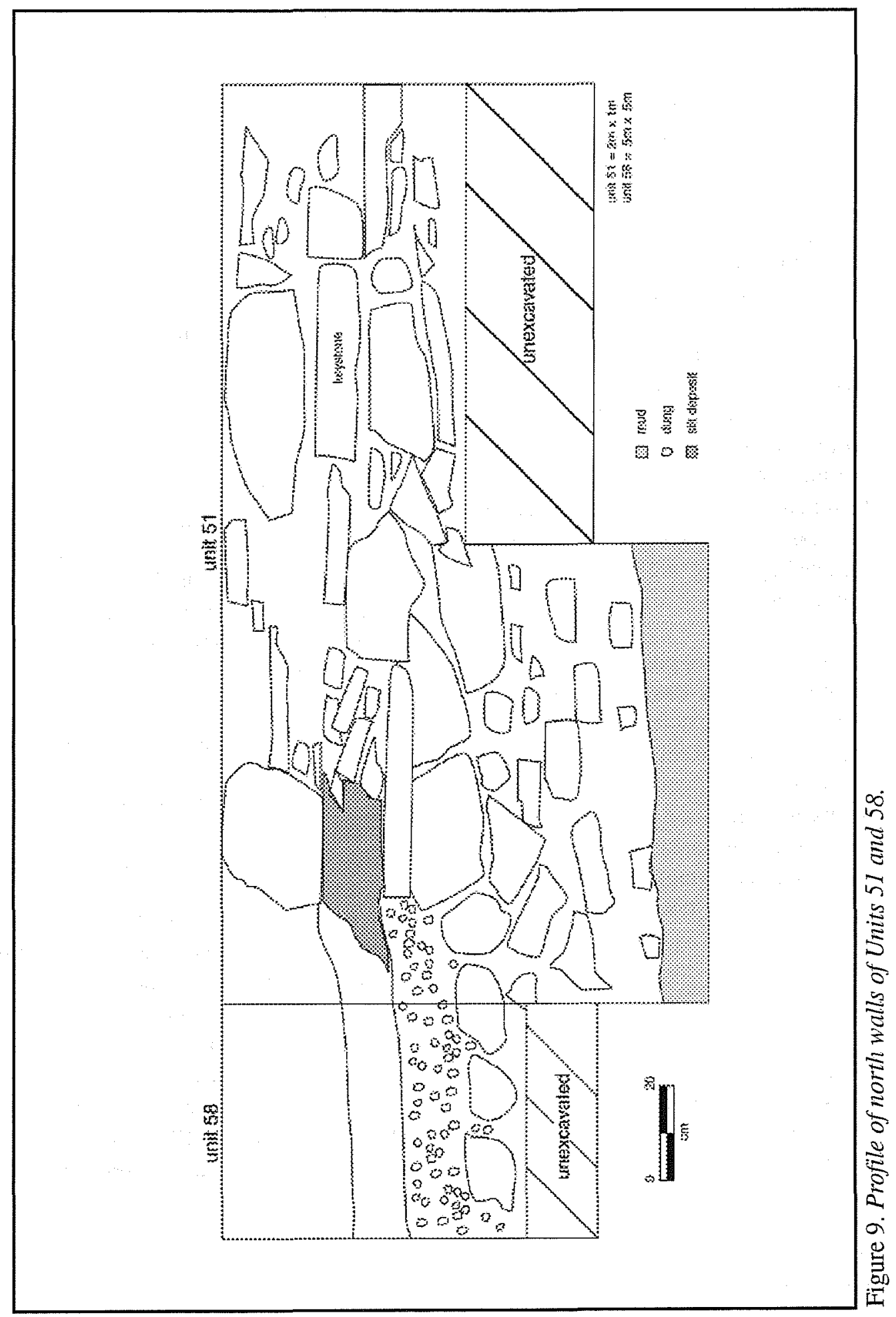


Layer 4 was not uniform in depth or content. The north half of the unit consisted of gray sand loosely packed with a high ash content and an abundance of charcoal. A concentration of burned bone was noted, but no other artifacts. The south half of the unit was tightly packed yellowish sand with a chalky lime mottling. Six sherds were recovered from the bottom two centimeters of this half of the unit, one a polychrome majolica and five Goliad ware.

The north half of Layer 5 was a tightly packed gray sand. It was hard and almost had the consistency of sandstone. The south half of the unit was a tightly packed yellow Sandy soil with a chalky lime mottling. Again, as in Layer 4, the soil was distinctly different in the two halves of the unit. As Layer 5 was excavated, it became evident that the tightly packed gray soil in the north half of the unit actually extended throughout the unit once the yellow sand layer was removed. The remaining hard packed gray sand surface contained flakes of charcoal and sloped from north to south. The beginning of a posthole was noted in the center of the unit.

The soil of Layer 6 was a hard packed gray sand with chalky lime mottling. A few flakes of charcoal were present in the matrix. A posthole was located $40 \mathrm{~cm}$ below datum in the center of the unit, $14 \mathrm{~cm}$ west of the wall. The posthole was $26 \mathrm{~cm}$ deep. Ceramics recovered from this layer included one sherd of undecorated majolica and two of unglazed ware. This layer was $18 \mathrm{~cm}$ deep, and the termination was arbitrarily chosen since there was no noticeable break in the stratigraphy.

\section{Observations}

The dung in Layer 3 probably represents several episodes of holding livestock within the compound. Just below the dung layer, the distinctive original occupation surface was encountered. It contained pockets of ash and charcoal indicating an early hearth or dumping activities. The wall footing trench appears to originate ca. $10 \mathrm{~cm}$ below the main occupation surface. This may mean that the wall was constructed before the time of the first intensive occupation, or at least the surface had not been modified until after the wall was in place. The depth of the footing trench is 53 $\mathrm{cm}$. The trench extends from 2 to $5 \mathrm{~cm}$ out from the inside face of the wall. The wall itself is $75 \mathrm{~cm}$ wide. The postholes found within the unit must have originated at least as early as the footing trench, and may represent early jacal or ramada construction. Similar postholes were found during the 1981 season along the west wall (Ivey 1983:Figure 2) and during the 1982 season along the south wall (Jones and Fox 1983:20).

\section{Unit 57}

Unit 57 adjoined the north side of Unit 49 on the east wall of the compound. It was excavated to the bottom of the wall footing. No evidence was found of a gateway in this unit.

If the entrance had a threshold stone, it was removed just prior to the introduction of livestock-holding activities on the site. There is no hard gray floor extending over the threshold. The footing in this area was found to be the same as that of the rest of the wall, except that the top row of footing stones is absent.

\section{Artifacts and Faunal Material}

\section{Anne A. Fox}

In order to aid in the interpretation of the results of this investigation, we have divided the artifacts into two time periods, the Spanish colonial period (ca. 1750 to 1820 ) when the ranch was in operation by the mission and the late nineteenth century when apparently various landowners continued to use the site for running livestock and probably briefly used the buildings for storage. This chronological pattern has been continuously observed since the first investigation in 1980 (Ivey and Fox 1981:30). Table 1 lists all the artifacts and faunal material recovered during the 1983 excavations.

\section{The Spanish Colonial Period}

The colonial artifacts found at this site are identical to those present on mission sites in San Antonio. They 


\begin{tabular}{|c|c|c|c|c|c|c|c|c|c|c|c|c|c|c|c|c|c|c|c|c|c|c|c|c|c|c|}
\hline \multicolumn{8}{|c|}{ un } & \multicolumn{6}{|r|}{$\vec{b}$} & \multicolumn{6}{|r|}{$\frac{1}{\infty}$} & \multicolumn{6}{|c|}{ 立 } & \multirow{2}{*}{ Unit } \\
\hline  & 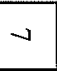 & $a$ & in & + & $\omega$ & 10 & - & $a$ & i & + & $\omega$ & 10 & - & 雚 & $u$ & + & $\omega$ & 10 & - & 亚 & in & + & $\omega$ & 10 & - & \\
\hline & & & & & & & & - & & & & & & & & & & & & & & & & & & Undecorated Majolica \\
\hline & & & & & & & & & & & & & & - & - & & & & & & & & & & & Hue jotzingo \\
\hline & & & & & & & & & & & & & & & & & & & & & & & & & & San Elizario \\
\hline & & & & & & & & & & - & & & & & & & & & & & & & & & & Polychrome \\
\hline & & & & & & & & & & & & & & & & & & & & & & & & & & Sandy Paste L.G. \\
\hline & & & & & & & & & & & & & & & & & & & & & & & & & & Fine Paste L.G. \\
\hline & & & & & & & & & & - & & & & & & & & & & & & & & & & Olive Jar \\
\hline & & & & & & & & & & & & - & & . & & & & & & ( & & & & & & Black Lustre \\
\hline 5 & 10 & $\infty$ & & 10 & & & & 10 & & in & $a$ & $a$ & - & - & - & ( & & 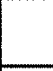 & & 10 & & - & & & & Goliad \\
\hline & & & & 10 & & & & & & & & & & & & 10 & & - & & & & & & & & Undecorated Whiteware \\
\hline & & & & & & & & & & & & & & & & & & & & & & & & & & Sponged White ware \\
\hline & & & & & & & & & & & & & & & & & & & & & & & & & & Tea Leaf Ironstone \\
\hline & & & & & & & & & & & & & & & & 10 & & & & & & & & & & Olive green glass \\
\hline & & & & & & & & & & & & & & & & & & & & & & & & & & Brown glass \\
\hline 10 & 10 & & & & & & & & & & & & & & & - & & & & & & & & & & Clear glass \\
\hline & & & & & & & & & & & & & & & & . & & & & & & & & & & .22 caliber shell \\
\hline & & & & & & & & & & & & & & & & & & & & & & 10 & & & & Rusted metal \\
\hline & & & & & & & & & & - & & & & & & - & & & & & & & & & & Grinding sonte \\
\hline$\omega$ & & - & & & & & & & &  & $\sim$ & - & & 10 & 10 & - & & & &  & & . & 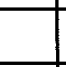 & & & Chert \\
\hline & & & & & & & & & & - & n & $u$ & - & $\omega$ & - & - & & & & 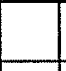 & & & - & & & Shell \\
\hline & & & & & & & & $\alpha$ & & $E$ & ü & 覃 & \begin{tabular}{|l}
$\infty$ \\
$i$ \\
in
\end{tabular} & in & & 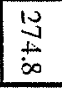 & & & & ă & & $\begin{array}{l}\overrightarrow{3} \\
3 \\
0\end{array}$ & $\vec{u}$ & & & Bone (grams) \\
\hline
\end{tabular}




\begin{tabular}{|c|c|c|c|c|c|c|c|c|c|c|c|c|c|c|c|c|c|c|c|c|c|c|c|c|}
\hline & & & & & & & & w & & & & & & & is & & & & & & & & $\because$ & Unit \\
\hline 尔 & $\infty$ & 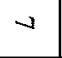 & a & u & + & $\omega$ & 10 & - & $\sim$ & $a$ & $u$ & + & $\omega$ & 10 & - & $\infty$ & $\sim$ & $\sigma$ & u & + & $\omega$ & 10 & - & Level \\
\hline & & & - & & & & & & & & & & & & & & & & & & & & - & Undecorated Majolica \\
\hline & & & & & & & & & & & & & & & & & & & & & & & & Huejotzingo \\
\hline & & & & & & & & & & & & & & & & & & & & & & & - & San Elizario \\
\hline & & & & & & & & & & & & & & & & & & & & & & & 10 & Polychrome \\
\hline & & & & & - & & & & & & & & & & & $\omega$ & & & & & & & & Sandy Paste L.G. \\
\hline & & & & & & & & & & & & & & & & & & & & & & - & & Fine Paste L.G. \\
\hline & & & & & & & & & & & & & & & & & & & & & & & & Olive Jar \\
\hline & & & & & & & & & & & & & & & & & & & & & & & & Black Lustre \\
\hline 13 & & $\omega$ & & & & 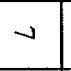 & & & $\omega$ & & & & & & & $\omega$ & & & 10 & & - & - & $\omega$ & Goliad \\
\hline & & & & & & & & & & & & & & & & & & & & & & & & Undecorated Whiteware \\
\hline & & & & & & & & & & & & & & & & & & & & & - & & & Sponged Whiteware \\
\hline & & & & & & & & & & & & & & & & & & & & & & & & Tea Leaf Ironstone \\
\hline & & & & & & & & & & & & & & & & & & & & & & & & Olive green glass \\
\hline & & & & & & in & & & & & 10 & & & & & & & & - & & $\omega$ & - & & Brown glass \\
\hline & & & & & & & & & & & & & & & & & & & & & + & + & $a$ & Clear glass \\
\hline & & & & & & & & & & & & & & & & & & & & & - & . & & .22 caliber shell \\
\hline & & & & & & & & & & & & & & & & & & & & $\omega$ & & - & & Rusted metal \\
\hline & & & & & & & & & & & & & & & & & & & & & & & & Grinding sonte \\
\hline- & & & & & & - & & & 10 & & & & & & & & & & & - & & & 10 & Chert \\
\hline & & & & & & - & & & - & & & & & & & & & & & & & & - & Shell \\
\hline  & & 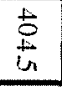 & & 0 & \begin{tabular}{|l|} 
\\
$u$ \\
0 \\
$i$ \\
$i$
\end{tabular} & & & & $\mid \begin{array}{c}\overrightarrow{0} \\
0 \\
\text { un }\end{array}$ & & $\begin{array}{l}\text { 台 } \\
\text { in } \\
\end{array}$ & & & & & 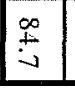 & \begin{tabular}{|l|} 
\\
0 \\
0 \\
\hdashline
\end{tabular} & \begin{tabular}{|l|l}
$\infty$ \\
$\infty$ \\
\end{tabular} & $\vec{n}$ & u & $\underset{\omega}{\omega}$ & & & Bone (grams) \\
\hline
\end{tabular}







include ceramics, wine bottle glass, and chert artifacts such as cutting and scraping tools and projectile points. Of these, the most useful for dating purposes are the Mexican-made ceramics on which the decoration changed over time. Compared to other seasons at las Cabras, this season's work recovered comparatively few artifacts from this period.

\section{Ceramics}

Ceramics are generally divided into groups according to their country of origin and/or surface finish. Goliad ware, a handmade, low-fired earthenware, was made by the Indians of south Texas before they entered the missions and continued to be made in the missions. An all-purpose cooking and storage ware, it was used by everyone in San Antonio until the early nineteenth century (see Figures 10d and 10e). Lead glazed earthenwares were brought to San Antonio by supply trains from Mexico throughout the eighteenth century. These were also primarily kitchen wares.

Majolica, a lead-and-tin-glazed earthenware made primarily in Puebla, Mexico, was brought to Spanish sites in limited quantities during the colonial period. Its brightly colored enameled designs changed in popularity with some regularity, allowing its use for dating archaeological sites and deposits within those sites. For example, the majolica patterns recovered during this season at las Cabras can be dated as follows:

Huejotzingo is decorated with a single blue band around and over the rim of plates, cups, and bowls. Dating for this type is broad, 1700 to 1850 (Deagan 1987:83).

San Elizario Polychrome has blue floral decorations accented with brown lines (Figures 10a and 10c). It was popular in the San Antonio River valley from 1755 to 1780 (Ivey 1982:37).

A number of polychrome designs were used on majolica during the eighteenth century. They range in date from Abó, 1630 to 1700 (Goggin 1968:172) to the Aranama series, 1750 to 1830 . Most of the frag- ments found during this season were too small to be able to separate them into specific types (Figure 10b).

One sherd of black luster ware traditionally made in Michoacan (Schuetz 1969:51) came from Unit 54, Layer 3.

Olive jars were traditionally used around the world for shipping olive oil and wine on Spanish ships. One such heavy, wheel-thrown vessel is represented by a sherd from Unit 49, Layer 4.

\section{Glass}

Olive green wine bottle fragments are common on Spanish colonial sites. Fragments of these bottles have been found in nearly every season's excavations at las Cabras.

\section{Stone}

Stone artifacts such as grinding stones, gun flints, and chert tools found on colonial sites indicate the continuity of traditions among the mission Indians. Handheld grinding stones or manos made from river cobbles are occasionally found, as are flakes of chert that have been made into tools or gun flints (Figure 10f). In addition, occasionally projectile points are also found. These are usually arrow points, or Guerrero points, popular in the mission period, but often at the missions there is evidence that earlier points have been collected by mission inhabitants and ended up in mission deposits. Such a point (Figure $10 \mathrm{~g}$ ) was found in post hole fill in Unit 48, along with a sherd of Huejotzingo majolica.

\section{Nineteenth Century Occupation}

After the secularization of Mission Espada, the lands of las Cabras were gradually divided up among the local citizens (see Jones and Fox 1983). Excavations in front of the chapel and inside and outside of Room 4 against the north wall have yielded a few nine- 


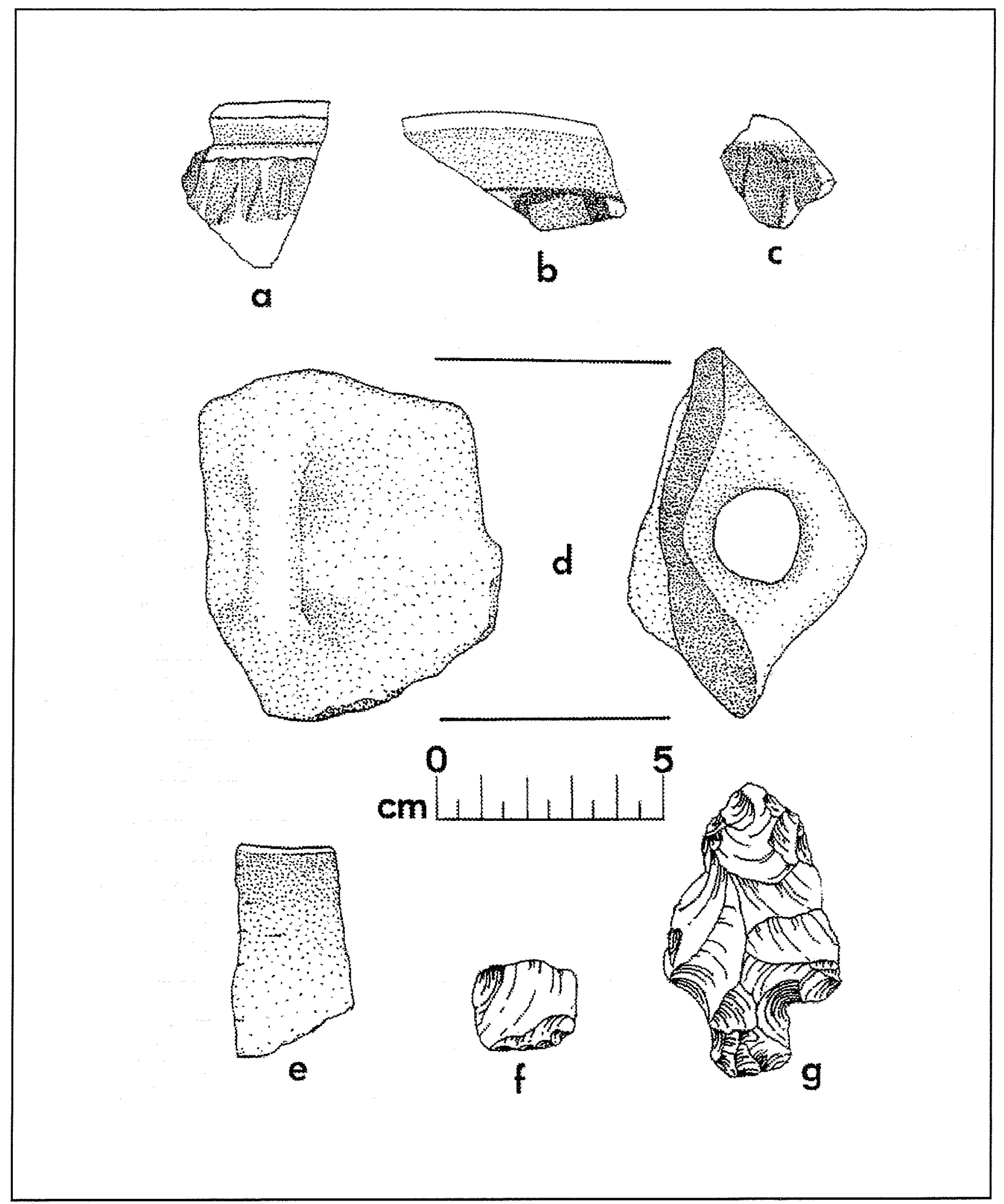

Figure 10. Selected artifacts from 1983 excavations. a: San Elizario majolica from Unit 56, Level 6; b: polychrome majolica from Unit 54, Level 4; c: San Elizario majolica from Unit 56, Level 4; d: Goliad ware from Unit 50, Level 6; e: Goliad ware from Unit 55, Level 4; f: possible pistol flint from Unit 56, Level 4; g: crude projectile point from Unit 48, Level 5 . 
teenth century artifacts suggesting that these areas continued in occasional use into that time.

\section{Ceramics}

Seven sherds of the heavy whiteware called ironstone were recovered from Units 48, 50, and 58. Of these, one represented the pattern Tea Leaf Ironstone, which reached its peak of popularity in the late nineteenth century and by 1910 had been reduced by housewives to use as feeding dishes for household pets (Ray 1974:221-222). One sherd of blue spatter ware came from Unit 51 outside the doorway of Room 4. This ware was imported into the San Antonio area from England starting in the 1830 s and pieces could have lingered in local kitchens until after the Civil War.

\section{Rusted Metal}

Numerous fragments of thin, rusted metal have been found throughout the compound. It is not possible to date these with any certainty, but most appear to be typical of the rusted food containers found on nineteenth century sites. It has been our experience that the only thin, sheet metal found on colonial sites has been fragments of copper vessels.

\section{Glass}

Glass. A number of fragments of brown and clear container glass were recovered in various locations on the site. These probably also represent nineteenth century deposition or the activities of treasure hunters in the early twentieth century.

\section{Ammunition}

One 22 caliber shell was found in level 3 of Unit 51 , which would put it on top of the older deposits which preceded the dung deposit. It is not possible to tell whether it originally sat at this level, however.

\section{Fauna}

The faunal identification list (Table 2) was compiled by William McClure.

Table 2. List of Identified Fauna from 1983

\begin{tabular}{|c|c|}
\hline Common Name & Genus \\
\hline Fresh-water clam & Genus unknown \\
\hline Gar & Lepisosteuss sp. \\
\hline Channel catfish & Ictalurus punctatus \\
\hline Unidentified fïsh & Genus unknown \\
\hline Water snake & Nerodiasp. \\
\hline $\begin{array}{l}\text { Western Diamondback } \\
\text { rattlesnake }\end{array}$ & Crotalus atrox \\
\hline Softshell turtle & Trionyx sp. \\
\hline Unidentified turtle & Genus unknown \\
\hline Turkey & Meleagris gallopavo \\
\hline Chicken & Gallus domesticus \\
\hline Eastern cottontail & Sylvilagus floridanus \\
\hline Fox squirrel & Sciurus niger \\
\hline Hispid cotton rat & Sigmodon hispidus \\
\hline Southern plains woodrat & Neotoma micropus \\
\hline Striped skunk & Mephitis mephitis \\
\hline Collared peccary & Tayassu tajacu \\
\hline White-tailed deer & Odocoileus virginianus \\
\hline Cow & Bos taurus \\
\hline Goat & Capra hirca \\
\hline Slueep & Ovis aries \\
\hline Unidentified mammal & Genus unknown \\
\hline
\end{tabular}




\section{Oral Histories}

\author{
Anne A. Fox
}

By the end of the third season of work at Rancho de las Cabras, it was becoming apparent that there might be local citizens who could provide important information about the nineteenth and early twentieth century history of the site, and that the ones who would have the most information were probably also the ones who were nearing the end of their lives and might not be with us too much longer. For this reason, we recommended that an effort should be made to locate and interview these people as soon as possible. When plans were formulated for the fourth season's work, we were given permission to undertake such a project.

\section{Methodology}

The first step in preparation for doing the oral history interviews was to find subjects who were of sufficient age to provide information on the time period for which we had little or no information who would be willing and able to talk with an interviewer. The period about which we had the least amount of information, except for the ownership history obtained through deed record research, was from secularization (roughly 1800) to the mid-twentieth century. Living informants might possibly be able to remember as far back as the last decade of the nineteenth century but no earlier. They might have some information in the form of local stories, but our experience with these already encountered made us suspect that the stories were more legend than history.

For the earlier part of the nineteenth century, we would have to rely on oral histories printed in the local newspaper. Fortunately, the Wilson County Historical Commission and various local historians have compiled scrapbooks and files, some of which are in private hands and some are in the local library. These have given us at least a glimpse of what was happening during that time.

A list of possible informants was compiled and of these several proved to be quite cooperative and helpful. A list of questions for which we needed answers was compiled along with a number of subjects we hoped might be in- cluded in the discussions. The idea of tape recording the interview was discarded when it seemed to worry several informants. Instead, the interviewer retired immediately to a quiet place and wrote out a summary of what had taken place.

\section{Graves Map}

A copy of a map done in 1902 by Everett Graves and copyrighted in 1934 by Adina DeZavala (DeZavala Collection in the Barker History Center) is reproduced here as Figure 11. Note that it shows a tower at the end of the section of wall extending from the southwest corner. If that structure was standing at that time, all traces of it have now been removed according to field notes from excavations in this area in 1981 on file at CAR. However, these excavations may not have extended quite far enough east to eliminate the possibility that such a defensive tower once existed. It is interesting that Graves did not show an entrance through the compound wall, although he correctly shows the splayed entrances to the rooms against the north wall.

\section{Scrapbook Clippings}

There were a number of early twentieth century snapshots in various collections showing the walls of the mission still standing higher than a man's head. A detailed and interesting personal interview appeared in the Floresville Chronicle-Journal. [FCJ] on September 16, 1960 (FCJ 1960a):

When I was a boy (1840-1850) there were still some big ranches on the river. I remember the Guilbeau place, then near Greytown, the Flores, and on down the river the Yndo, Francisco Flores, Rafael Herrera, Juan Seguin and the Lucas Calvillo ranchos.

The very first road to Matamoras went right by the Old Goat Mission, then angled west. It was known as a very ancient road when I was young. In those days the Chapel of the Mission was still in use and was very beauti- 


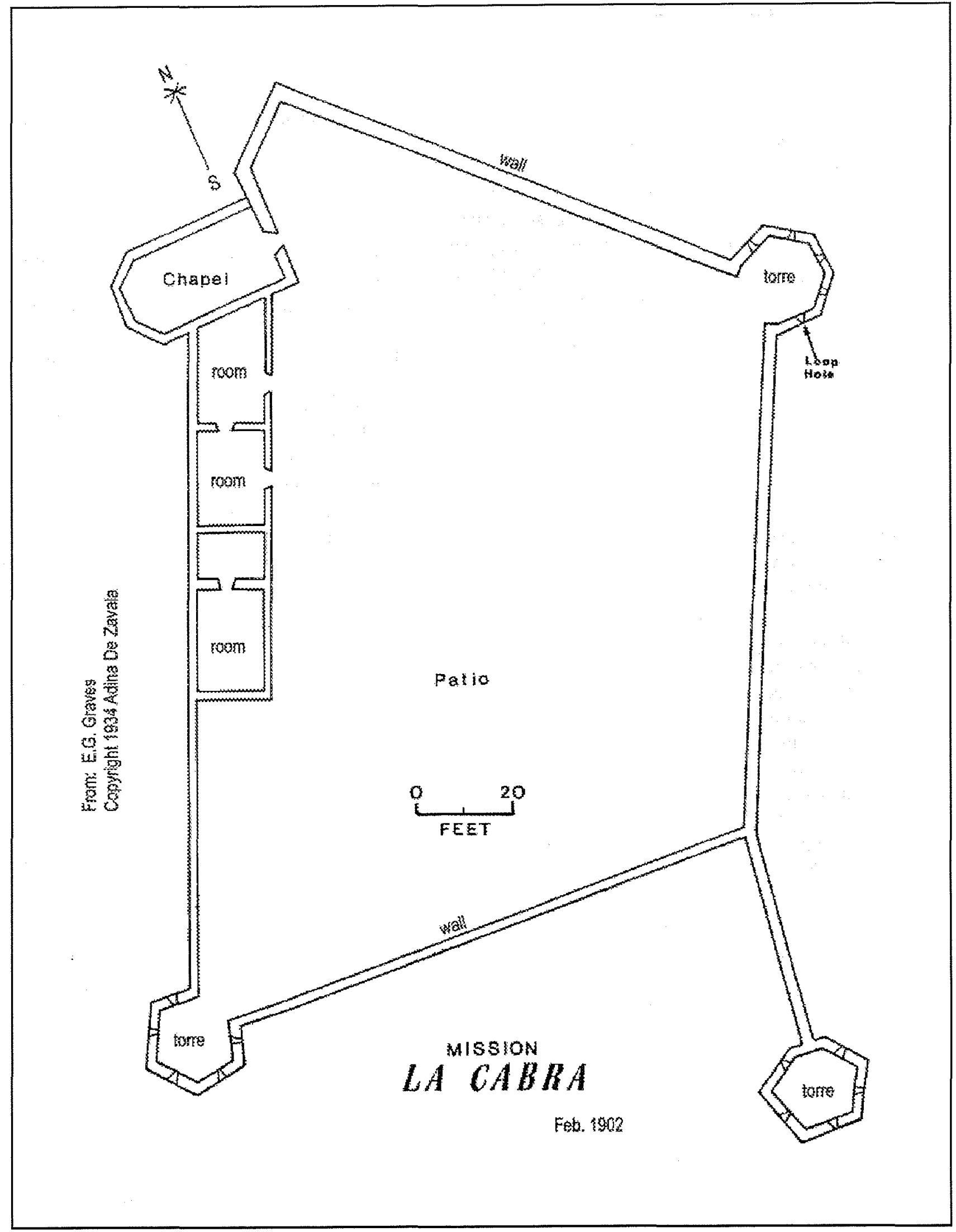

Figure 11. The E. G. Graves 1902 map of las Cabras. 
ful. . I also remember seeing the walls of the old Goat Ranch house. They were all that were left in the fifties. They were below the river from the Mission on Tordilla Hill.

I have heard that in the 'muy antigua' (probably 1800-1820) as many as twenty families lived on Calvillo ranch. When warned of the Indians, all would come to the big house for protection. Maria Calvillo would mount her horse with her pistols and a carbine from which a white rag flew and ride out to meet the savages (she gave beeves to the Indians and they never bothered her place).

Also in the same paper (FCJ 1960b), another article reports:

Old Mexicans around the country say they have heard from fathers and grandfathers that services were held in the chapel. They say there had been a well in the patio and that there was supposed to have been a tunnel leading to the river. The stone from the old mission has nearly all been hauled away. Everything is overgrown with brush and cactus. People have dug up all around, hunting for treasure. The owners have placed a sign, 'Dig all you please, but do not remove rock from the walls' (Garret 1960).

\section{Zook Interview}

On July 12, Fox met with Mr. and Mrs. Warren Zook at their home. Although Mr. Zook protested that there was not much he could tell us, it turned out that he provided an interesting glimpse of the ranch site in the early twentieth century.

Mr. Zook's father was a missionary. They came to Floresville ca. 1905 when the informant was about five years old. His father founded the El Mesias Mexican Methodist Church in town.

As a boy, Mr. Zook wandered all over the las Cabras area. He remembered sitting on the walls and watching Roman candles being shot off in Floresville on the fourth of July. The chapel walls were very high, all the perimeter walls were at least partially standing, and there were loopholes in the north wall. $\mathrm{He}$ said the ground was pretty level in those days, "before people started digging for treasure". The rooms against the north wall were standing to roof height, but he was not sure whether any of the roofs still remained. There were wooden lintels still in place over some doors and windows.

There had been no services in the chapel "for a long time". The only gate he remembered was somewhere to the west (he was vague about the exact location), but there was only one. The only digging Mr. Zook did was outside the walls, where he found a bunch of goat bones and nothing else.

He once owned the property directly south of the site and rode over it often. He saw no stone ruins in the property directly to the south of the rancho. There was some sort of a jacal structure on his place, however. He has heard nothing about the Barrera ownership of that property in the past.

\section{Flores Interview}

On July 20, Fox interviewed Mr. Ignacio Flores in his drugstore in Floresville. He had little memory of las Cabras other than a vague picture of tumbled walls overgrown with vines and brush. However, he suggested an interview with Andres Courvier, who was at that time over 90 years old.

\section{Courvier Interview}

Mr. Andres Courvier graciously stopped cutting the grass in his front yard to talk with Fox for a few minutes. The only memory he had of las Cabras was of walls about "this high" (ca. $3 \mathrm{ft}$ ), and finding bags of arrowheads in the vicinity. He had heard that there was a tunnel to the river, but never saw it. He knew nothing about a well in the compound. 


\section{Albert Interview}

On July 26, Mary Jane Moczygemba took Fox to visit with Mr. and Mrs. Ervin Albert in their home. They drove to the site of las Cabras and conducted most of the interview there. Fox talked principally with Mr. Albert, with occasional interjections from his wife. Mr. Albert was ca. 87 years of age and nearly totally blind, but had an excellent memory. His wife was ten years younger.

Mr. Albert's father bought 355 acres, which included the las Cabras ruins, in 1906 (Mr. Albert would have been about ten years old at the time). They lived there four years in the house next to the road, which is the farmhouse still standing on the Southern property.

Mr. Albert vividly remembered entering the rancho through an "arched" gate (actually this was flat on top). There was a stone room to the left, in front of which was a deep cistern (maybe 15 or $16 \mathrm{ft}$ deep). The walls were all standing over eight feet high. A photo taken of him and his wife there in 1927 when they went back to visit (Figure 12) shows a cut stone wall over 10 feet high and a doorway maybe 5 feet wide. The walls were thick enough and flat on top so that you could walk on top of them. (This appears to be the entrance doorway of the chapel, since it is too narrow to be the entrance gate to the rancho). The Alberts were uncertain about the location of this doorway. It might be the entrance to the chapel.

There was a door opening toward the cistern from the stone-walled room mentioned above. Outside the walls there was a caved-in area where a tunnel toward the river once had been located (perhaps Mr. Zook's excavations).

A wooden fence was standing across the compound, possibly the one for which the traces have been found during this season's work. There was talk of a cemetery, but he did not know where it was located.

The towers were a little higher than the walls. There were square holes in the walls. The inside of the compound was entirely open, and a Mr. Carver rented it to set up his bee hives there because it was protected from the cattle. There was a small wall extending straight out from the southwest corner, but no tower on the end of it. He knew nothing about a chapel, and did not remember noticing it particularly or hearing anything about church services being held out there. His father installed double gates in the opening into the compound to protect it.

The stone robbing took place after they had left. The land was bought in 1904 for $\$ 7.00$ an acre and sold in 1910 for $\$ 14.00$ an acre.

\section{Ziegler Interview}

On July 28, Fox visited with Louis Ziegler in his home on County Road 133. He moved to his present location when he was six years old, in 1911. Once when it was too wet to work in the fields, his father took him and his brother over (ca. one mile distant) to look at the ruins. The perimeter wall was rubble, no towers were standing, and he did not notice the chapel. The building against the north wall was standing up to the eaves, with one roof beam still in place. He did not remember noticing doors or windows. His father cut into the roof beam and the center was red (cedar?). He remembered the cistern as being outside the north wall.

He could report no local stories or traditions about the site, except that there were ghosts around the ruins. Twenty years later he took a Boy Scout troop there and all was in worse ruins.

\section{Discussion}

Mr. Villareal's reference to local families "forting up" in the ranch house in the 1820 s bears out the complaint of Manuel Barrera, who held land to the south, that Indian raids had forced him to abandon his ranch in 1830 (Jones and Fox 1983:9). Villareal's memories evidently began in the 1840 s while Maria Calvillo was alive. She began to sell off parts of the property in 1844 and 1845 . It seems possible that the chapel continued in use occasionally during Maria's later years (she died in 1856) even though she had actually sold the property to Edward Dwyer in 1845 (BCDR Vol C2:42; Jones and Fox 1983:11). The fact that Dwyer, 


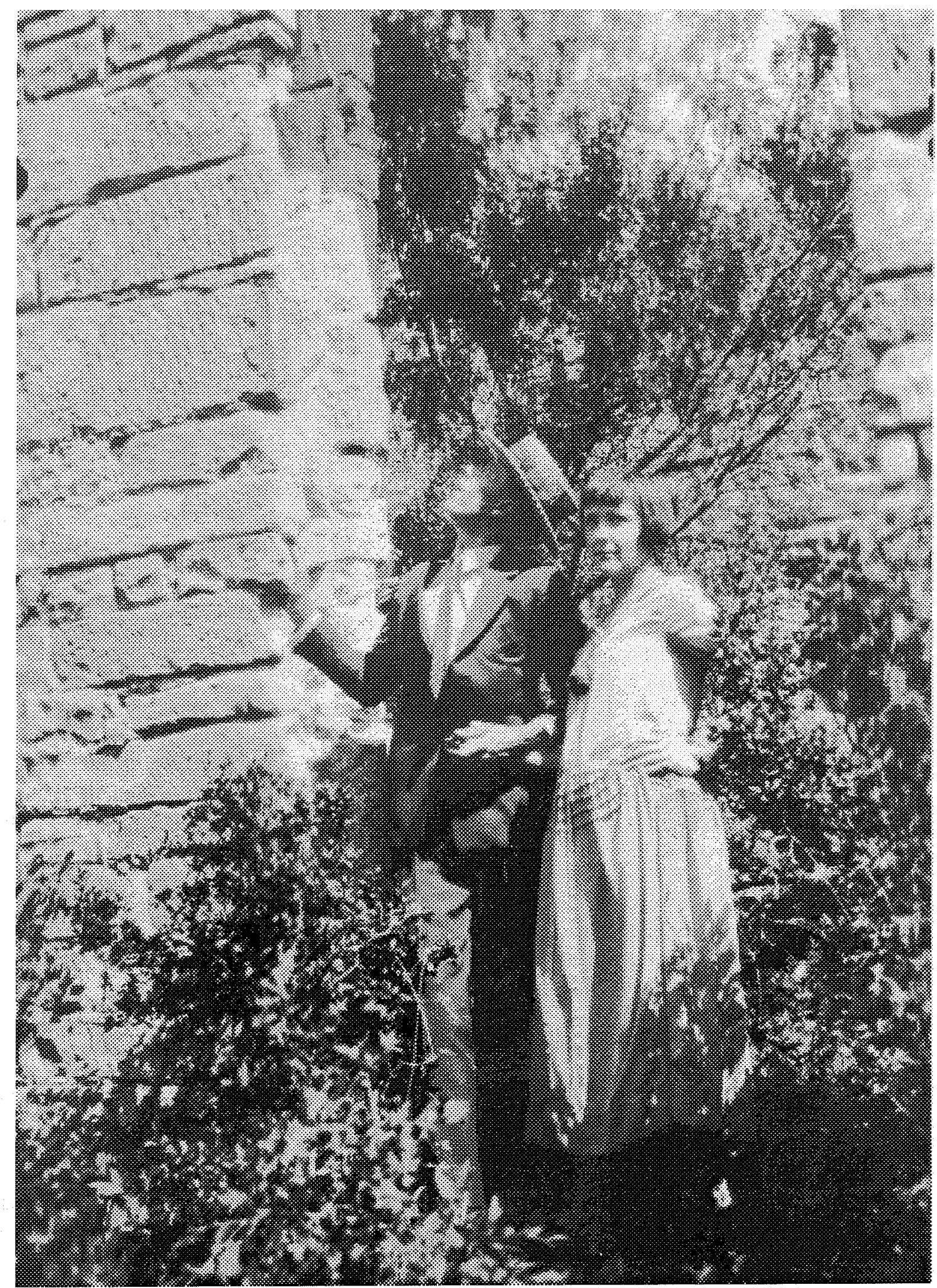

Figure 12. Photograph of Mr. and Mrs. Ervin Albert at las Cabras in 1927. Note the height and condition of the walls. This is presumably the door to the chapel. 
a prominent citizen of San Antonio, was an absentee landowner may have encouraged local people to continue to use the property in the $1850 \mathrm{~s}$.

Nothing in the Villareal interview was helpful in deciding when, by whom, and for whom the chapel was built. Since they were not mentioned in the 1772 Inventory, we propose that the chapel and the rooms against the north wall were built after that date, probably near the end of the mission period. It does not seem likely, from what we know about her so far, that Maria Calvillo had the resources to be able to construct such sturdy stone buildings.

Mr. Zook, born in 1900, and Mr. Albert, born in 1896 , appear to have observed the site at about the same time, around 1906 to 1910 . The chapel had evidently gone out of use quite a while before that time. Judging from Mr. Ziegler's interview, by the 1920 s the roofs had fallen in and the walls were beginning to crumble but were still standing up to the eaves in some places. It appears from Mr. Albert's interview that a substantial amount of the walls were still standing until at least 1927. It may be that this was because stone robbing and treasure hunting did not really get started until after this date.

\section{Summary}

Anne A. Fox

The fourth season's archaeology was concentrated in the area of the northeast corner and the east wall of the compound. The goals for the season were to study the relationship between the chapel and adjacent walls and rooms, to search for the second gate, and to compile oral histories by interviewing local residents who had memories of the site.

The foundation of the south wall of Room 3 was examined and documented, along with a doorway to the room and the intersection of the foundations of this wall and the chapel wall. A curving trench containing postholes was found to extend from the southwest corner of the chapel toward the east wall of the compound. The number of postholes and their pattern and the absence of large postholes that would indicate structural corners, suggest that this was a picket-type fence, probably for corralling small animals such as sheep or goats. The deep layers of animal dung containing scattered sheep/goat bones throughout this section of the compound tend to confirm this supposition. The location of the second gate could not be positively identified by the methods used in this season's work. The results of the oral history research suggest that there is little more to be learned except from old newspaper accounts of interviews of early residents of the area.

\section{Recommendations}

\author{
Anne A. Fox
}

Judging from the results of this season's work, added to what was learned during the previous three seasons, we are now approaching the point where larger excavation areas will be necessary in order to better understand the sequence of events at the site. The following areas should be examined in detail before any attempt is made to interpret the history of the site to the public:

1. The trash dump outside the northwest gate (Ivey 1983:10-12). It appears that the artifacts most important to understanding the inhabitants of the site during mission times are located in this area. This feature was examined in 1984 with a series of shovel tests during the fifth season investigations at las Cabras. The shovel testing indicated that the midden has a limited horizontal distribution (Taylor and Fox 1985).

2. The entire jacal area within the northwest corner (Ivey 1983:12-16). Only carefully controlled and recorded excavations will allow the interpretation of the sequence of building in this area.

3. The complex series of corrals and walls within the northeast corner in front of the chapel (Jones and Fox 1983:23-32; also Figure 2 this publication). 
4. The entire floor of the chapel. This should be excavated in cooperation with specialists in stabilization and preservation, as there are likely to be painted frescoes on the buried portions of the plastered interior walls and removing the soil on the interior of the chapel will endanger the stability of the walls.

5. In addition, a concerted effort should be made to find the research papers of Mildred Burrows Garret, who lived at 1409 Winsted Lane, Austin, Texas, in 1960. According to an article in the Floresville Chronicle-Journal of September 16, 1960, (Section A, page 6) she interviewed many Wilson County pioneers "back in the thirties" and made careful notes.

With the exception of the first recommendation, none of these avenues of research were undertaken during the subsequent 1984 season (Taylor and Fox 1985). No scientific excavations have been conducted at the ruins of las Cabras since the end of the 1984 season. 


\section{References Cited}

Black, S. L.

1989 Environmental Setting. In From the Gulf Coast to the Rio Grande: Human Adaptation in the Central, South, and Lower Pecos Texas, edited by T. R. Hester, S. L. Black, D. G. Steele, B. W. Olive, A. A. Fox, K. J. Reinhard, and L. C. Bement, pp. 5-17. Research Series No. 33. Arkansas Archeological Survey, Fayetteville.

Blair, W. F.

1950 The Biotic Provinces of Texas. Texas Joumal of Science 2(1):93-117.

Deagan, $\mathrm{K}$.

1987 Artifacts of the Spanish Colonies of Florida and the Caribbean, 1500-1800. Vol. 1. Ceramics, Glassware, and Beads. Smithsonian Institution, Washington D.C.

Floresville Chronicle-Journal (FCJ)

1960a [Bruno Villareal] 16 September:A6.

1960b [Applewhite House] 16 September:G8.

Goggin, J. M.

1968 Spanish Majolica in the New World, Types of the Sixteenth to Eighteenth Centuries. Yale Publications in Anthropology 72. Department of Anthropology, Yale University.

Ivey, J. E.

1983 Archaeological Testing at Rancho de las Cabras, 41 WN 30, Wilson County, Texas, Second Season. Archaeological Survey Report, Number 121. Center for Archaeological Research, The University of Texas at San Antonio.

Ivey, J. E., and A. A. Fox

1981 Archaeological Survey and Testing at Rancho de las Cabras, Wilson County, Texas. Archaeological Survey Report, Number 104. Center for Archaeological Research, The University of Texas at San Antonio.

Jones, C. J, and A. A. Fox

1983 Archaeological Testing at Rancho de las Cabras, Wilson County, Texas, Third Season. Archaeological Survey Report, Number 123. Center for Archaeological Research, The University of Texas at San Antonio.

Labadie, J.

1988 Archaeological Excavations at the Shrew Site 41 WN73 Wilson County, Southern Texas. Contract Reports in Archaeology, Report No. 2. Texas State Department of Highways and Public Transportation, Austin. 
McClure, W.

1983 Bone. In Archaeological Testing at Rancho de las Cabras, Wilson County, Texas. Third Season, by C. J. Jones and A. A. Fox, pp. 34-38. Archaeological Survey Report 123. Center for Archaeological Research, The University of Texas at San Antonio.

Nordt, L. C.

1996 Geoarchaeology of Leon Creek, Texas: Hausman Surface Water Project. Archaeological Survey Report, Number 234. Center for Archaeological Research, The University of Texas at San Antonio.

1997 Geoarchaeology of Site 41BX126 Along Culebra Creek in Bexar County, Texas. Manuscript on file, Center for Archaeological Research, The University of Texas at San Antonio.

Ray, M.

1974 Collectible Ceramics, An Encyclopedia of Pottery and Porcelain for the American Collector. Crown, New York.

Schuetz, M. K.

1969 The History and Archeology of Mission San Juan Capistrano, San Antonio, Texas. Vol. II. Report 11. State Building Commission Archeological Program, Austin.

Steele, D.G., and C.A. Hunter

1986 Analysis of Vertebrate Faunal Remains from 41MC222 and 41MC296, McMullen County, Texas. Appendix III. In The Prehistoric Sites at Choke Canyon Reservoir, Southern Texas: Results of Phase II Archaeological Investigations, by G.D. Hall, T.R. Hester, and S.L. Black, pp. 452-502. Choke Canyon Series 10. Center for Archaeological Research, The University of Texas at San Antonio.

Steel, D. G., and G. B. DeMarcay

1985 Appendix C. Analysis of Faunal Remains Recovered During the 1984 Excavations at Rancho de las Cabras. In Archaeological Survey and Testing at Rancho de Las Cabras, 41 WN30, Wilson County, Texas, Fifth Season, by A. J. Taylor and A. A. Fox, pp. 62-75. Archaeological Survey Report, No. 144. Center for Archaeological Research, The University of Texas at San Antonio.

Taylor, A. J., and A. A. Fox

1985 Archaeological Survey and Testing at Rancho de las Cabras, 41WN30, Wilson County, Texas, Fifth Season. Archaeological Survey Report, Number 144. Center for Archaeological Research. The University of Texas at San Antonio.

Taylor, F. B.

1977 Soil Survey of Wilson County, Texas. Soil Conservation Service, United States Department of Agriculture, Washington, D.C. 
